\title{
Role of regional extension and uplift in the Plio-Pleistocene evolution of the Aksu Basin, SW Turkey
}

\author{
CLARE P. GLOVER ${ }^{1} \&$ ALASTAIR H. F. ROBERTSON \\ Department of Geology and Geophysics, University of Edinburgh, West Mains Road, Edinburgh EH9 3JW, UK \\ ${ }^{1}$ Present address: Esso Exploration and Production UK, MP 25, Ermyn Way, Leatherhead, Surrey KT22 8UY, UK
}

\begin{abstract}
The Aksu Basin, within the Isparta Angle area of SW Turkey, documents Plio-Pleistocene crustal processes at the interface between the Tauride Mountains and the Eastern Mediterranean Sea. Basin sedimentation began in the Late Miocene, following an earlier history of emplacement of Mesozoic allochthonous units (Antalya Complex), Miocene basin development and localized Late Miocene compression (Aksu Phase). Late Miocene-Early Pliocene transtension deformed the Aksu Basin, exploiting pre-existing zones of structural weakness. During Early-Mid-Pliocene, muddy sediments accumulated in a shallow shelf sea $(<150 \mathrm{~m}$ deep), open to the Mediterranean Sea to the south. Regression in the Late Pliocene then resulted in coarse deltaic progradation. Mature erosion surfaces developed on adjacent elevated areas throughout the Pliocene and were accompanied by fanglomerate deposition along the high-relief western margin of the basin. East-west extension then formed the present Aksu Basin as a $\mathrm{N}-\mathrm{S}$ half graben in the Late Pliocene-early Pleistocene associated with greatly enhanced fluvial downcutting. Accumulation of very extensive $\left(600 \mathrm{~km}^{2}\right)$ and locally thick (up to $250 \mathrm{~m}$ ) cool-water Antalya tufa deposits then followed, prior to glacial times. Initial localized lacustrine carbonate deposition was followed by development of mainly algal carbonates that are thickest in the west. The terraced nature of the tufa (terraces at 300,250,100 m above present sea level) is explained in terms of fluvial processes. Regional comparisons suggest a two-stage history for the Aksu Basin: first, Late Miocene-Early Pliocene transtension and subsidence; secondly, Late Pliocene-Early Pleistocene rifting and marginal uplift. The overall tectonic setting reflects interplay between supra-subduction zone extension and tectonic 'escape' of Anatolia westwards towards the Aegean.
\end{abstract}

Keywords: Turkey, Pleistocene, Pliocene, tectonics, sediments.

The Eastern Mediterranean is one of the best areas for the study of continental collision processes. Different areas range from fully collisional in the east (i.e. Zagros), to others undergoing incipient collision further west (e.g. Aegean). The present Africa-Eurasia plate boundary is defined by the concave southwards Cyprus and Aegean arcs that are now relatively well known through a combination of land and marine studies, including deep-sea drilling. However, the critical area linking the two active margin segments remains poorly understood. This area includes an important basin within Antalya Bay that extends northwards onto land, the Plio-Pleistocene Aksu Basin within an area known as the Isparta Angle of SW Turkey (Fig. 1). The Aksu Basin demonstrates an interaction between the uplifting central Anatolian plateau, the extending Aegean and the Mediterranean active margins undergoing subduction. The area links the marine geology of the Eastern Mediterranean Sea with the continental tectonics of Anatolia to the north.

The purpose of this paper is to describe and interpret the Plio-Pleistocene evolution of the Aksu Basin, in its regional tectonic context, based on integrated sedimentological, structural and geomorphological studies. This area is ideal for this work as Plio-Pleistocene sedimentary and geomorphological features are well exposed and can be correlated with offshore marine deposits using shallow seismic data. Also, the Miocene and earlier tectonic history is well known. Onshore, Late Miocene transgressive marine basinal sediments are succeeded by diverse Plio-Pleistocene units, including shallow-marine shelf sediments, coastal deltaic and alluvial deposits and extraordinarily extensive tufa deposits.
The Aksu Basin is located at a critical interface between several contrasting tectonic regimes. To the north and east of the Aksu Basin, strike-slip faulting and regional uplift dominate. In the west several $\mathrm{E}-\mathrm{W}$-trending grabens mark an extensional regime. Areas to the south can be considered to lie within a 'back-arc' setting of the present northward-dipping Africa-Eurasia plate boundary.

The sedimentary history of the Aksu Basin is a sensitive indicator of regional tectonic processes, including uplift of the Tauride Mountains to the north, rifting within the Isparta Angle and relative subsidence to the south within Antalya Bay. Being essentially coastal, the sediments can be correlated with the effects of a Mediterranean-wide sea-level curve that is now relatively well understood (Wornardt \& Vail 1991; McKenzie et al. 1990; Thunnel et al. 1990). It is thus possible to interpret the relative importance of local and regional tectonics versus 'eustatic' sea-level change on depositional processes.

During the Mesozoic-Early Tertiary, the eastern Mediterranean region, including the Isparta Angle area is envisaged as a series of small oceanic basins, which underwent predictable stages of rifting, spreading, subduction/accretion, displacement/ emplacement and collision (Robertson et al. 1991, 1996a). Diachronous collisions ensued from the Late Cretaceous onwards in the 'Turkish area' and were particularly dominant during the Late Eocene and Miocene. Locally derived carbonate platforms, together with volcanic seamounts and ophiolite material, were thrust onto the adjacent margins of small Neotethyan ocean basins, with the Antalya Complex bordering the Isparta Angle being a well-documented example of such processes (Poisson et al. 1984; Robertson \& Woodcock 1984). 


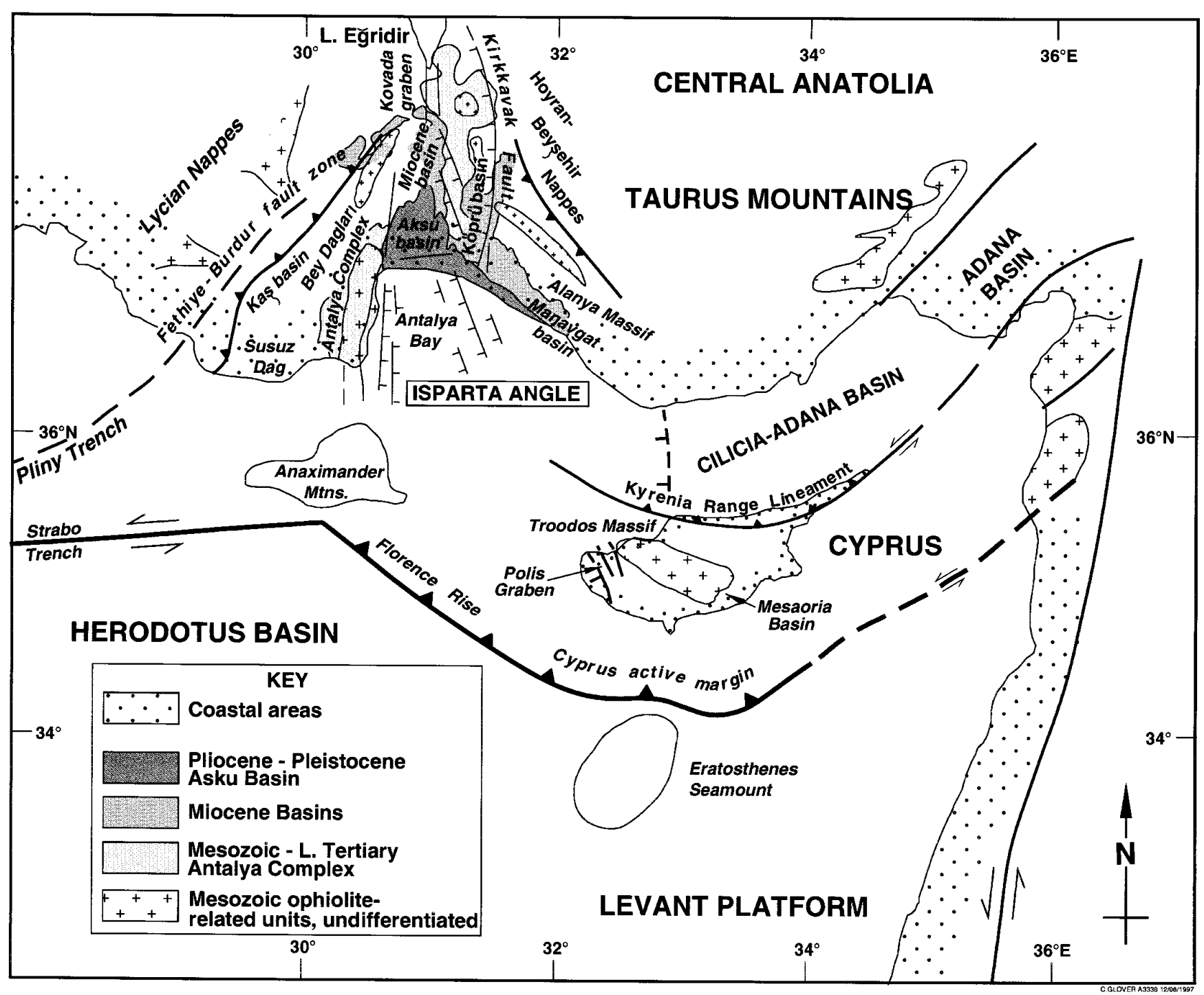

Fig. 1. Outline tectonic map of the easternmost Mediterranean area, showing the main Neotectonic lineaments and the main structural units and basins mentioned in the text.

The Isparta Angle is a triangular-shaped region, bounded to the east and west by arcuate lineaments related to several discrete phases of thrusting and strike-slip (Fig. 1). In this area, the Antalya Complex (Antalya Nappes) was emplaced onto adjacent Mesozoic carbonate platforms in latest CretaceousPalaeocene time. Separate systems of thrust sheets were later emplaced from the northeast in the Late Eocene (HoyranBeyşehir Nappes), and from the northwest in the Late Miocene (Lycian Nappes), respectively (Poisson 1977; Frizon de Lamotte et al. 1995; Woodcock \& Robertson 1982; Robertson \& Woodcock 1984; Robertson 1993). This was followed by erosion, then subsidence in the Miocene to form the Miocene Aksu Basin, one of several related basins in southern Turkey (including the Köprü and Manavgat Basins) (Akay et al. 1985; Flecker et al. 1995; Flecker 1995). The Miocene Aksu basin is interpreted as a foreland basin related to southeastward emplacement of the Lycian Nappes, modified by extensional, or transtensional faulting (Flecker 1995). The eastern margin of the Miocene Aksu basin was affected by short-lived compressional deformation in the Late Miocene (Aksu Phase of Poisson 1977), associated with final emplacement of the Lycian
Nappes and tightening of the Isparta Angle (Kissel \& Poisson $1986 a, b$; Kissel et al. 1993). This was followed by crustal extension, or transtension in the Tortonian-Messinian (Late Miocene) to form the Pliocene-Pleistocene Aksu Basin, that is the main focus of this paper.

\section{Stratigraphic setting}

The lowest units above deformed Miocene sediments (Flecker 1995) in the Aksu Basin are Late Tortonian reef limestones (Gebiz Limestone) and minor gypsum of assumed Messinian age (not in situ). The lowest extensive unit comprises shallowmarine clastic sediments of the Yenimahalle Formation and this, in turn, is overlain by the deltaic to alluvial Çalkaya Formation that also includes minor tuffaceous deposits. Further west, along the coast southwest of Antalya, are the Kemer Fanglomerates. These deposits are believed to be approximately contemporaneous with both the Yenimahalle and Çalkaya Formations. In the northwestern part of the Aksu Basin fanglomerates are overlain by very extensive cool-water 


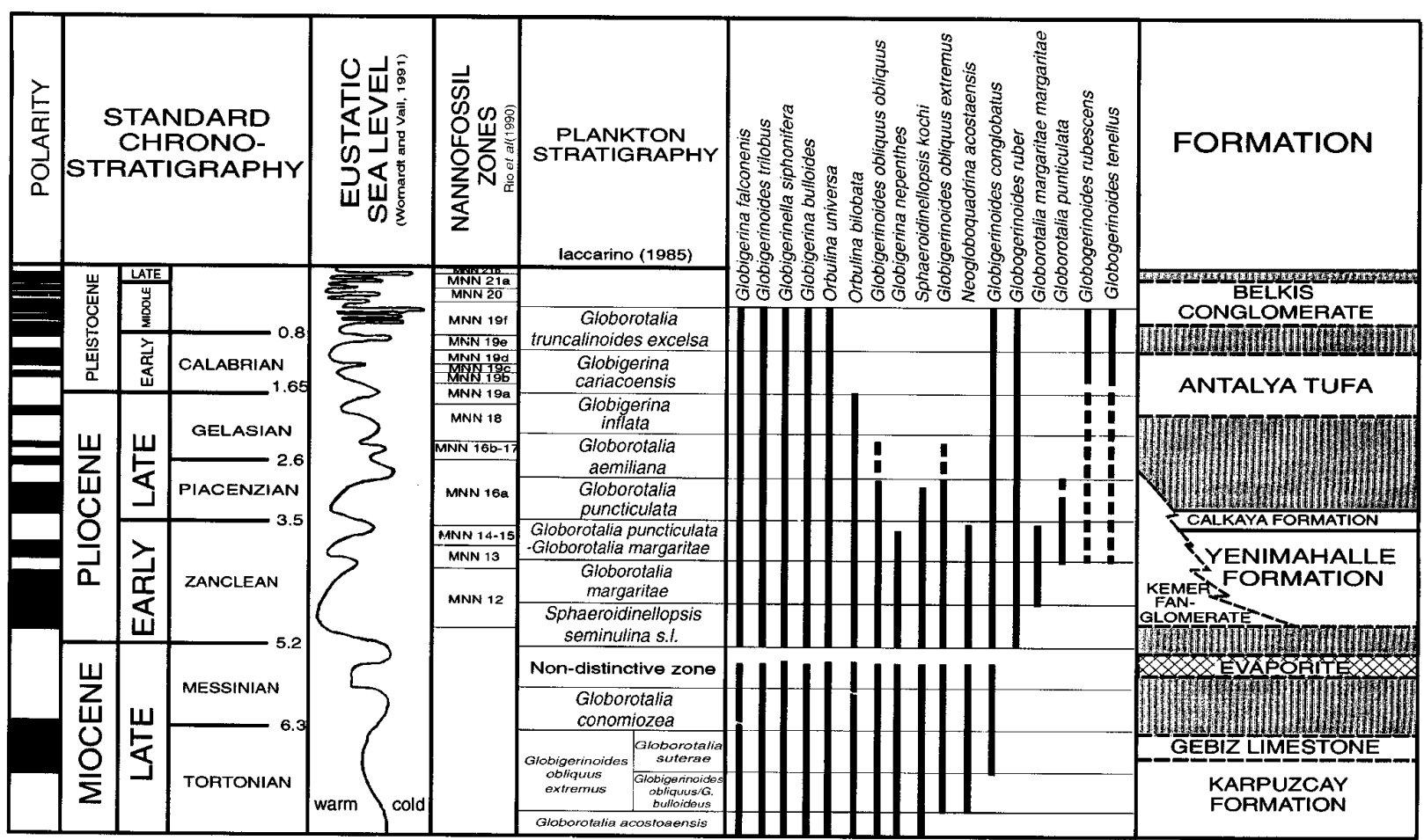

Fig. 2. Revised stratigraphy of the Plio-Pleistocene Aksu Basin, modified from Akay et al. (1985). Note that Çalkaya Formation is a combination of Akay et al.'s Eskiköy and Alakilise Formations. Dotted lines indicate uncertain stratigraphic boundaries; solid lines are more certain. Stratigraphic position is assigned using a combination of planktic foraminifera and calcareous nannoplankton, sedimentological field observations, and $\mathrm{K}-\mathrm{Ar}$ and $\mathrm{U}-\mathrm{Th}$ isotopic dating. The stratigraphic range diagram determined for the upper part of the Yenimahalle formation (Glover 1995) is included.

tufa deposits (the traditional 'Antalya Travertine'). The youngest extensive units are alluvial conglomerates (Belkis Conglomerate) exposed in the centre of the basin. Locally Terra rossa-type palaeosols are redeposited in steep-sided channels.

The stratigraphic subdivision discussed above and presented in Fig. 2 builds upon previous work by Akay \& Uysal (1985), Akay et al. (1985) and Poisson (1977), with additional dating and fieldwork (Glover 1995). Biostratigraphy and K-Ar dating shows that the Yenimahalle Formation and the Çalkaya Formation are of Early Pliocene, latest Zanclean age (Globorotalia puncticulata-Globorotalia margaritae zone, Fig. 2). The depositional period of the Kemer Fanglomerate is also inferred to be Early-Mid-Pliocene, based on lithological correlation (see below). Deposition of much of the Pliocene sedimentary succession probably took place during the Zanclean sea-level highstand (e.g. Wornardt \& Vail 1991). The uppermost part of the marine succession, the Çalkaya Formation, is placed within nannofossil zone NN15/16 (C. Müller pers. comm. 1994). K-Ar dates from biotites extracted from tuff within this formation are consistent with this age assignment, but are not conclusive, owing to excessive atmospheric argon adsorption on biotite. U-Th dating on samples from the tufa indicates an age greater than the maximum resolution of the method (>400 000 years).

The distribution of the various facies and location of the sedimentary successions documented here are shown in Fig. 3 for the Aksu Basin and Fig. 4 for the Manavgat Basin further east, modified after Akay \& Uysal (1985). Pliocene sediments are situated in the west of the Aksu Basin, dipping at up to $20^{\circ}$ beneath horizontal Pleistocene tufa deposits. In general,
Pliocene sediments of the Aksu Basin dip and young to the west. Working anticlockwise around the basin, the following marginal relations are seen. In the Manavgat area (Fig. 4), the Pliocene onlaps marine sediments of the Miocene Manavgat Basin with only a low-angle discordance. In the east of the Aksu Basin (Fig. 3), Pliocene sediments onlap Upper Miocene (Tortonian) reef limestones (Gebiz Formation). The reef limestones appear to have undergone extensional faulting, followed by local evaporite deposition. In the northeast to north, Pliocene sediments onlap Mesozoic units of the Antalya Complex (e.g. Haciosmanlar area). In the far north, onlap is onto nearly vertical terrigenous turbidites of the Miocene Aksu Basin (near Kayrak village). In the northwest, the northernmost area of the Aksu plain, Late Pliocene conglomerates (Çalkaya Formation) unconformably overlie Miocene (Karpuzçay Formation) sediments. Finally, in coastal areas to the southwest of Antalya (i.e. around Kemer), Plio-Pleistocene units unconformably overlie mainly steeply dipping and strongly deformed units of the Mesozoic Antalya Complex.

Seismic data from Antalya Bay offshore from the Aksu Basin indicate that the marine Pliocene is approximately $500 \mathrm{~m}$ thick and contains three transgressive events that can probably be related to eustatic sea-level changes. Although of poor quality, the seismic data also indicate that the Pliocene sediments overlie a block-faulted topography, defining an asymmetrical graben opening towards the south. The faults on the eastern margin appear to be larger than those on the western margin. Sediment channels can be identified within this graben and show a long-axis, mainly southward, transport direction. The sediments on the eastern flank of the graben can be correlated with the Pliocene sediments onshore. Some 


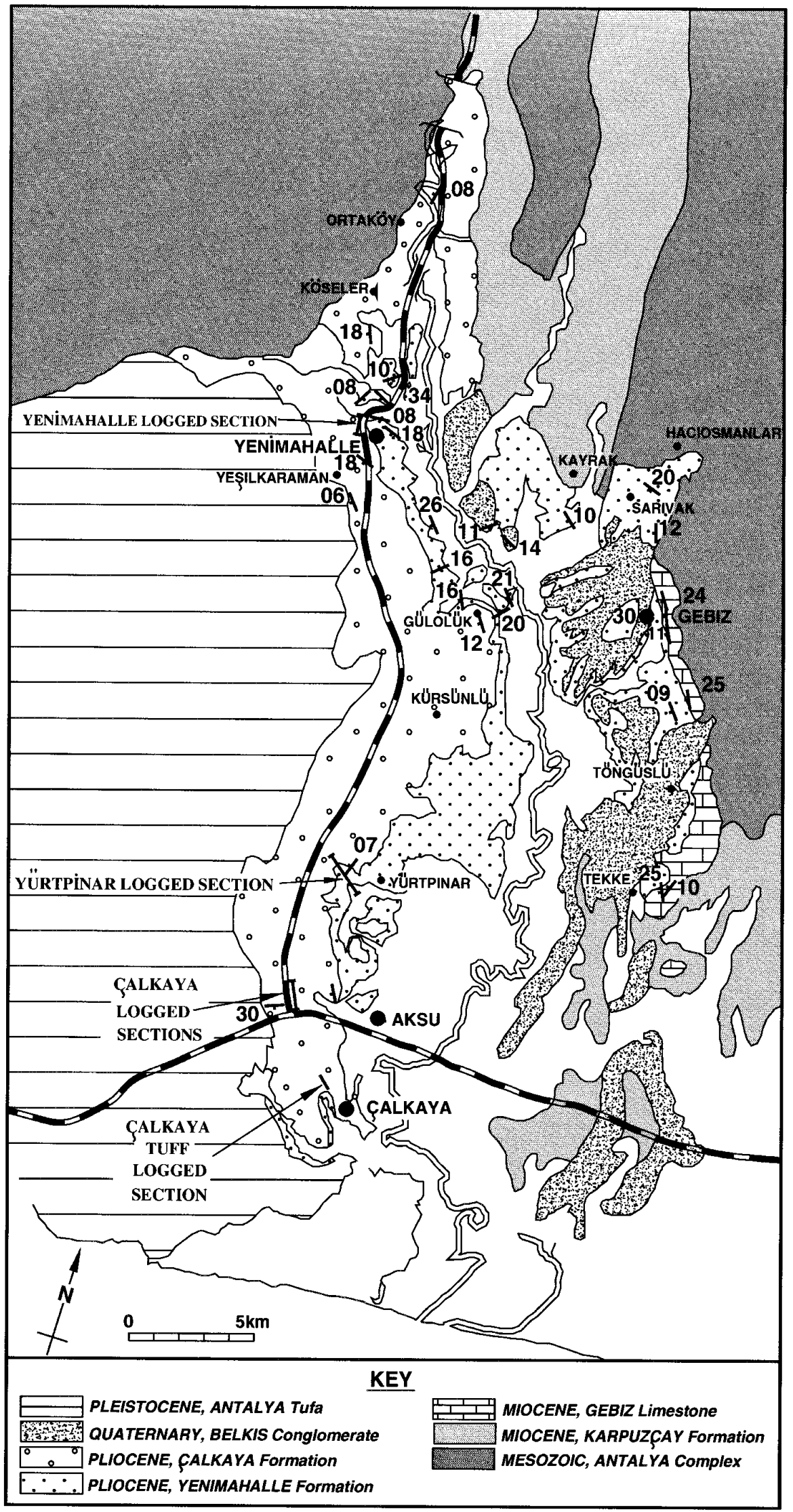

Fig. 3. Map of the Aksu Basin, modified from Akay \& Uysal (1985) and utilizing the new stratigraphy set out in this paper. The successions logged (i.e. Yurtpınar, Yenimahalle, Aksu and Çalkaya) are also indicated. 


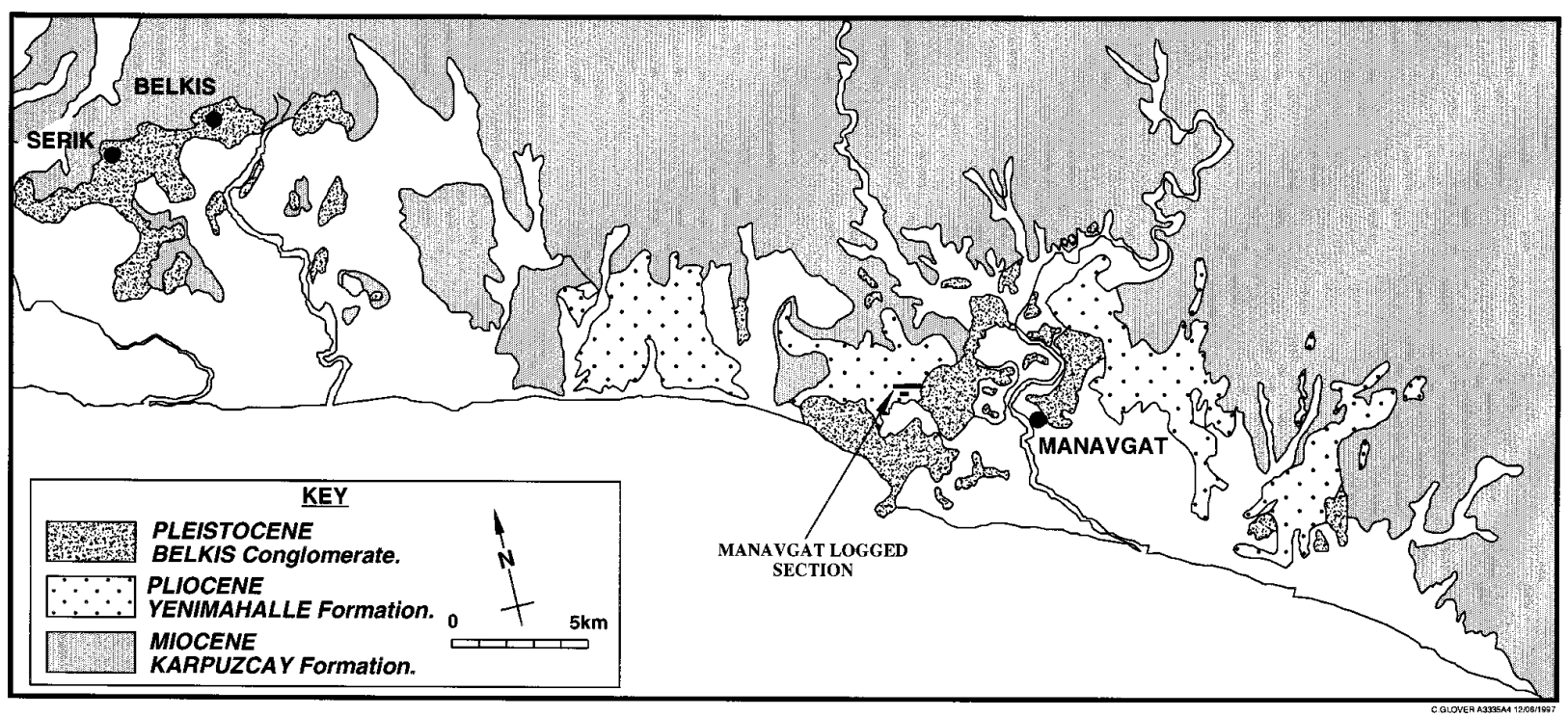

Fig. 4. Geological map of the Manavgat Basin, located to the east of the Aksu Basin. Modified after Akay \& Uysal (1985). Location of the Manavgat logged succession is indicated.

normal faults post-date deposition of the inferred Pliocene succession.

The Antalya Tufa is horizontally bedded and unconformably overlies all previous facies onshore. The lowermost beds are typically gastropod-bearing, clay-rich, microcrystalline tufa, or oncolitic carbonate as patches or lenses. The boundary between these and the underlying sediments is sharp. These lowermost beds pass upwards into laminated algal mat deposits, as much as $30 \mathrm{~m}$ thick in the east. In the west (around the Karaman gorge, Fig. 5), tufa, up to $250 \mathrm{~m}$ thick, unconformably overlies Mesozoic peridotites and radiolarites, based on outcrop and borehole data. Locally, a small hill composed of peridotite (Kelkayrak Tepe) is interpreted as a pre-existing topographic high around which tufa was deposited, leaving the summit protruding.

Conglomerate (i.e. Belkis Conglomerate) forms terraces bordering the present-day Aksu River. This unit is limited to the central Aksu valley and relates to incision and aggradation of the Aksu River during the Pleistocene. All units are incised by steep-sided channels filled with redeposited terra rossa-type palaeosols originally developed on the limestone basement and the tufa. These are interpreted as evidence of fluvial reworking, possibly during flash-flood events.

\section{Pliocene Yenimahalle Formation: shallow-marine shelf deposits}

The lowest part of the Yenimahalle Formation is exposed in the east around Manavgat. The succession is dominated by blue-grey siltstone with thin interbeds of medium and fine sandstones, in which sparse macrofossils occur (Fig. 6). Coarser, graded, gravel beds and a conglomerate body $(3 \mathrm{~m}$ thick) occur towards the top of the succession.

The stratigraphically lowest marine exposure in the Aksu Basin, further west, is blue-grey siltstone with sparse macrofossils. Stratigraphically higher, logging at Yenimahalle and Yurtpinar (Fig. 7) of recently exposed, fresh sections reveals channelization, lenticular sands, shell lag concentrations and soft-sediment deformation within background blue-grey silt- stones. Depositional sedimentary structures have been largely destroyed by pervasive bioturbation. The succession then grades upward into golden-brown, fine- to medium-sands with occasional lenses of gravel. There is an overall upward increase in shell size and diversity, typically including Acanthocardia sp., Ostrea sp., Cerastoderma edule, Paphia sp., Dentalis sp., Antalis sp., Apporais sp., Buccinum sp., Concus sp., Gibbula sp., Murex sp., Litterina sp., Fusinus sp., Balanus sp., and pectens. Numerous burrows include concentrations of Skolithos, Chondrites, Thalassanoides, Scoyenia and Planolites and Rind burrows. Sedimentary structures in the upper part of the Yenimahalle Formation include low-angle cross-bedding, trough cross-bedding, parallel lamination, ripple lamination, fining-upwards sand channels, gravel/conglomerate lenses and channels, as well as thicker conglomerate intercalations (with clasts up to $30 \mathrm{~cm}$ in size), scattered pebbles and occasional blackened wood fragments. Some beds have been disrupted by dewatering on a scale of $0.5 \mathrm{~m}$ to $1 \mathrm{~m}$ thick. Near the top of the succession palaeosols are locally developed, suggesting a correlation with the non-marine Çalkaya Formation (see later). Lithologies near the base of the succession are lithic greywacke (Folk 1974; Pettijohn 1975), or clayey siltstone (Picard 1971) and contain polymict, angular grains $(0.1-0.25 \mathrm{~mm}$ in size), set in a clay matrix ( $50 \%$ and $70 \%$ by volume). Biotite, muscovite and green pyroxenes are observed locally. The sandier upper sections are litharenites composed of moderately well-sorted, subangular to subrounded grains $(0.5 \mathrm{~mm}$ in size $)$, including chert, quartz, calcite, plagioclase and mudstone intraclasts.

Benthic foraminifera from both the Manavgat and Yurtpinar successions can be used to determine palaeowater depths and environments, when compared with ecological data from modern environments (Murray 1991; Table 1). Pullenia, Lenticulina and Planulina are indicative of a normal-marine environment. However, the small size of both planktic and benthic foraminifera and the scarcity of planktic Globorotalia species suggest that the sea was extremely shallow $(<50 \mathrm{~m})$. The presence of Nonion sp. in two samples from the Manavgat part of the succession suggests water depths of approximately $150 \mathrm{~m}$. Planktic/benthic ratios are typically between 1.5 and 7.0. The assemblage from the Yurtpinar succession is 


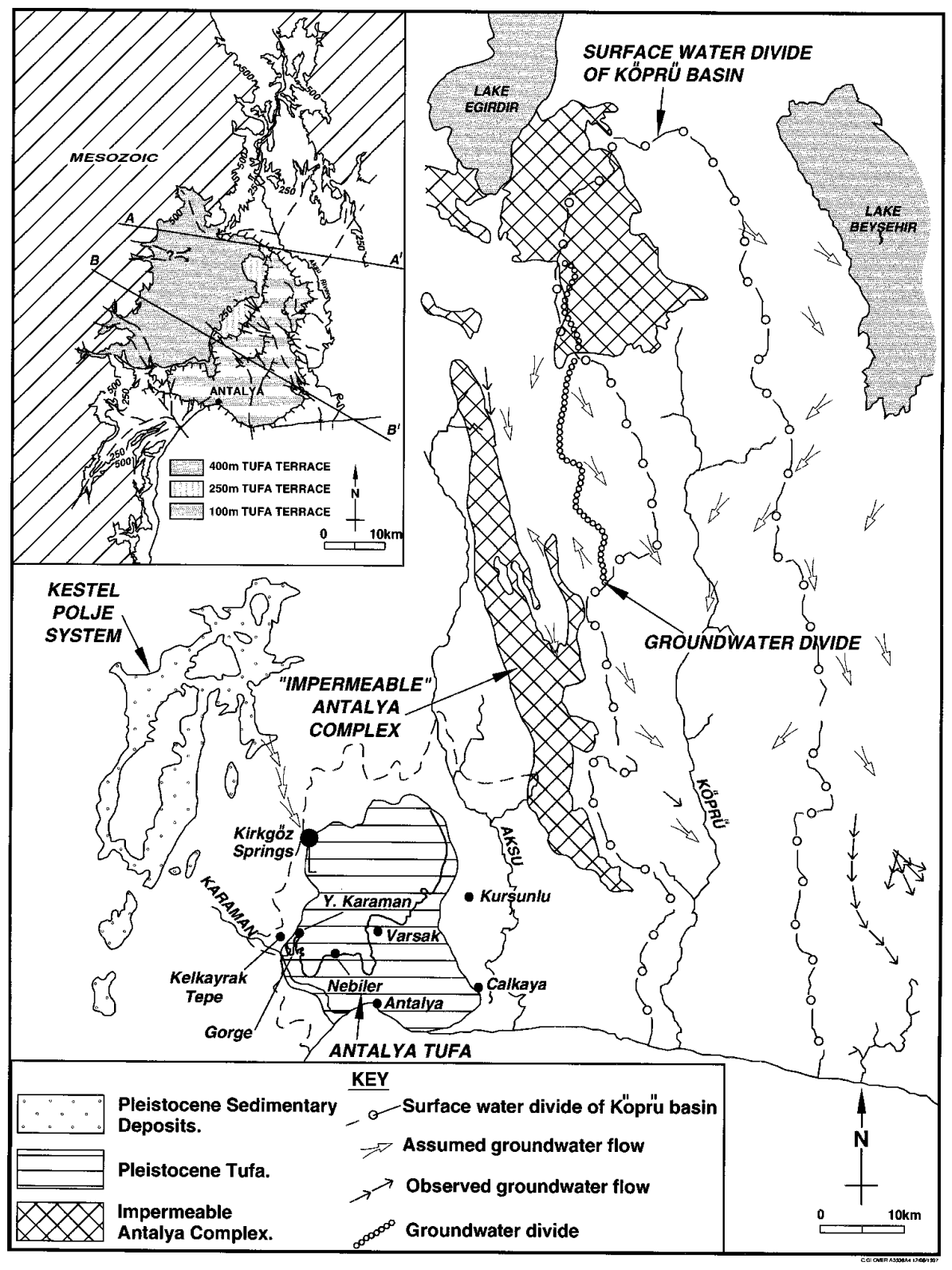

Fig. 5. Sketch map to show the inferred flow of groundwater in the Köprü basin (from Değirminci \& Günay 1992). Water is assumed to flow to the Köprü basin from the Eğridir/Beyşehir areas where large lakes exist. Impermeable lithologies within the Mesozoic Antalya Complex (e.g. shales) create a groundwater divide, effectively separating the Aksu and Köprü basins (Değirminci \& Günay 1992). Groundwater has probably travelled similar distances through the Aksu Basin. The Kestel Polje system in the NW is thought to be an important source of groundwater in the Aksu Basin feeding the springs at Kirkgöz (Burger 1990). The inset map of the western part of the Aksu Basin shows the series of major terraces that dominate the landscape. Lines of section $\mathrm{A}-\mathrm{A}^{\prime}$ and B- $\mathrm{B}^{\prime}$ through these terraces refer to cross-sections in Fig. 18. Dashed stream paths represent the probable location of eroding streams during wet glacial periods.

suggestive of an inner-shelf environment, between 0 and $100 \mathrm{~m}$ deep. Planktic/benthic ratios are generally between 0.15 and 0.5. Species of Ammonia, Planorbulina and keeled Elphidium suggest depths of $<50 \mathrm{~m}$ in the upper part of the formation, as previously inferred by Planhol (1956).

\section{Pliocene Calkaya Formation: deltaic complex}

The overlying Pliocene Çalkaya Formation is equivalent to the Alakilise and Eskiköy Formations of Akay et al. (1985). New outcrop at the north of the basin shows that the Eskiköy Formation unconformably overlies the marine Yenimahalle Formation and is equivalent in age to Akay's Alakilise Formation. The two units have therefore been combined and renamed the Çalkaya Formation as it is principally exposed in this area.

The Çalkaya Formation, up to $20 \mathrm{~m}$ thick, is dominated by heterogeneous coarse clastic sediments. The formation is gradational upwards from the underlying marine silts and sands of the Yenimahalle Formation. In the southern part of the basin, marine, marginal-marine and subaerial deposits are interbedded (Fig. 8). Most contacts are depositional and facies units are frequently lenticular. By contrast, fluvial conglomerates dominate in the northern part of the basin.

Mapping of the Aksu region shows that the Çalkaya Formation is cut by anastomosing east-west striking faults. A syn-sedimentary origin is shown by beds thickening towards fault traces, sediment draping of pre-existing fault scarps, associated soft-sediment deformation and related folding. The following sediment types are observed within the Çalkaya Formation.

\section{Sandstones}

Much of the Çalkaya Formation consists of sandstones similar to those of the underlying Yenimahalle Formation, with the same fossil assemblage. Exceptionally large specimens of the gastropod Murex sp. are noted locally. In general, marine 


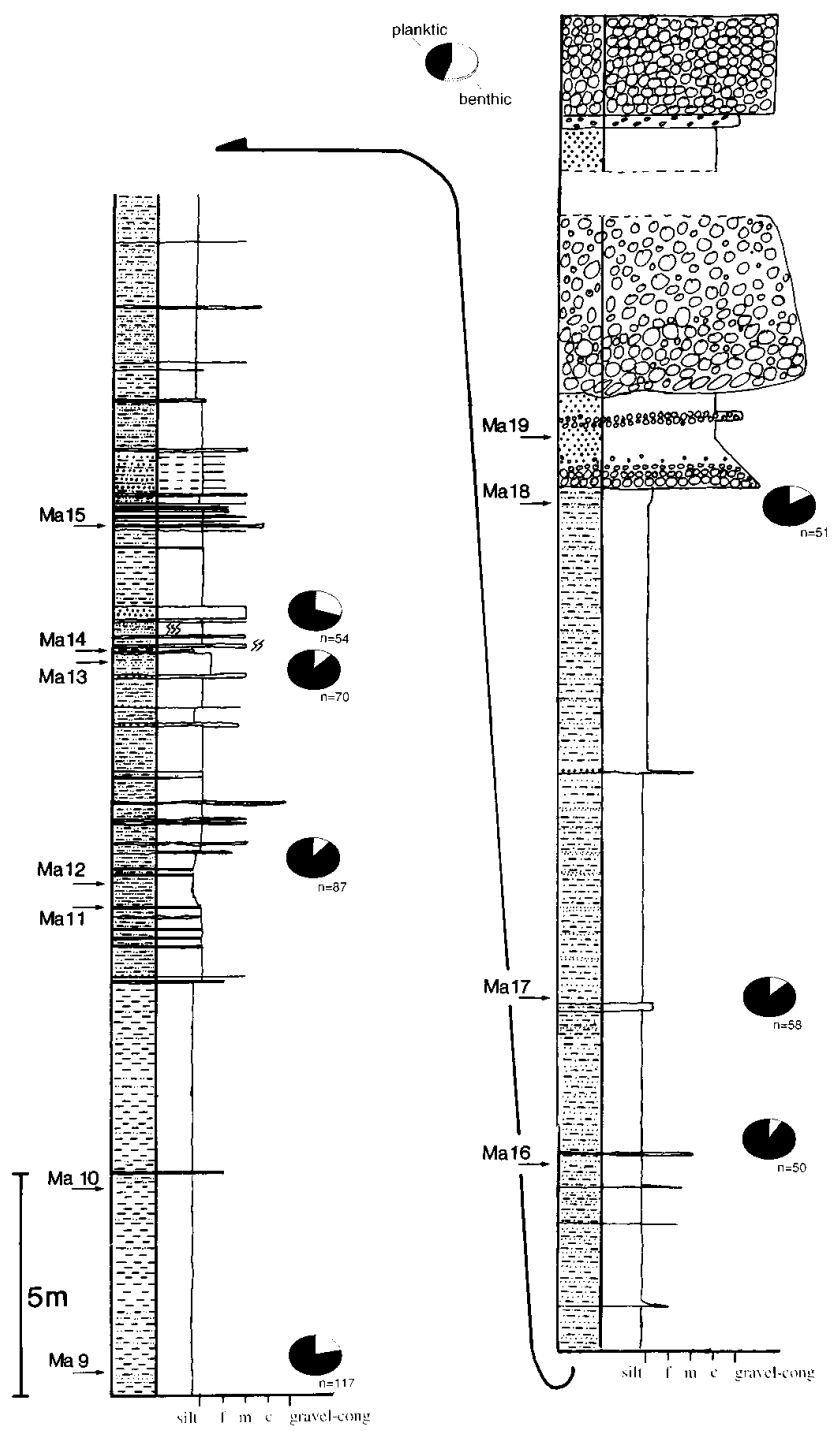

Fig. 6. Sedimentary log of the main Manavgat succession, located on the Manavgat road. Sample locations are shown on the left-hand side of the log. Pie charts represent ratios of planktic to benthic foraminifera (see Fig. 4 for location of section).

gastropods and bivalves in the Çalkaya Formation are larger than counterparts in the upper part of the Yenimahalle Formation. Many are in life position. Sedimentary structures (Fig. 8) include symmetrical ripples, low-angle cross-bedding, trough cross-bedding, mud drapes, ripple lamination and shell lags (e.g. Çalkaya area). Hummocky-cross stratification is seen locally. Carbonaceous material is relatively common. Burrows include Skolithos and Thalassanoides. The sands are interpreted as shallow marine in origin, subject to occasional storm activity.

\section{Southerly marine conglomerates}

Thin, tabular beds and small, lenticular deposits of conglomerate and gravel are interbedded with sandstones throughout the area. However, much larger conglomerate bodies are also found within the Çalkaya Formation (e.g. in the Çalkaya area) to the south. These conglomerates crop out as topographic ridges and map out as elongate bodies, parallel to bedding.
The beds are several metres thick and are commonly crossbedded (e.g. at Kurşunlu and Yeşilkaraman). Limestone clasts predominate over other components, including chert, sandstone and mudstone. The conglomerates are usually bimodal, with a matrix of silt to coarse sand varying from 10 to $50 \%$ by volume within individual beds. The median clast-size distribution is $1-5 \mathrm{~cm}$, with clasts reaching $12 \mathrm{~cm}$. In addition, there are small lenticular sand bodies (e.g. $13 \mathrm{~m}$ wide $\times 1 \mathrm{~m}$ thick), particularly in more northerly areas. Minor diagenesis is marked by slight dissolution of some limestone clasts, and small quantities of sparry calcite cement, especially around pebble edges.

The Çalkaya Formation conglomerates are marine in origin, as indicated by the evidence of pebbles bored by sponges and marine bivalves. Barnacles (Balanus sp.) and bivalves (cf. Pododesmus sp.) attached to pebbles and marine shells are rarely observed within the sandy conglomerate matrix. Limited palaeocurrent data are suggestive of onshore, offshore and longshore current activity (e.g. Clifton 1973), assuming the coastline was approximately parallel to that today. Pebble segregation and low lenticularity in the Çalkaya Formation are qualitative indicators of wave-worked conglomerates. Small, lenticular pebble bodies within well-sorted sands are interpreted as lag concentrations within the lower shoreface zone, possibly a result of accumulation in hollows, or as storm deposits (Kumar \& Sanders 1976; Bougeois \& Leithold 1984). Well-preserved, symmetrical ripples of gravel overlain by a fine matrix are suggestive of an upper shoreface environment (Bougeois \& Leithold 1984). Large outcrops of cross-stratified conglomerates are interpreted as migrating bars. In addition, channelized conglomerates contain sand bars.

\section{Brackish-water sediments}

Locally, faunas are restricted to salinity tolerant species, e.g. thin-shelled oysters, or Cerastoderma edule, suggestive of a brackish-water environment. Throughout the Çalkaya Formation, thin layers of carbonate-rich claystone ( $<1 \mathrm{~m}$ thick) occur. This may be as interbeds within sands draping symmetrical ripples, or as thin horizontal bands within tuffs (e.g. in the Çalkaya Formation). Small, flat and pulmonate gastropods are rarely found within these deposits. Carbonates are also present as bands of matrix within marine conglomerates. Comparable carbonate-rich clays in the Dead Sea basin are deposited from hypersaline waters in undisturbed isolated, evaporative lagoons and pools (Frostick \& Reid 1989), and a similar depositional setting is envisaged for the white claystones of the Çalkaya Formation.

\section{Palaeosols and coals}

Palaeosols, including coals, are relatively common within the Çalkaya Formation. Typical palaeosols, 1-2 m thick, are pale, brown Mediterranean-type soils, with an upper humic layer c. $50 \mathrm{~cm}$ thick, a visible leached zone and a lower zone of reprecipitation containing caliche nodules. Coals are well developed at two localities and less well developed, or very restricted, at others. The best example overlies a $10 \mathrm{~m}$ thick conglomerate, of which the $20-30 \mathrm{~cm}$ interval directly below the coal is well cemented and weathered red. Fissile coal, $75 \mathrm{~cm}$ thick, is separated from a second coal layer, $50 \mathrm{~cm}$ thick, by a bed of silt, $1 \mathrm{~m}$ thick. 

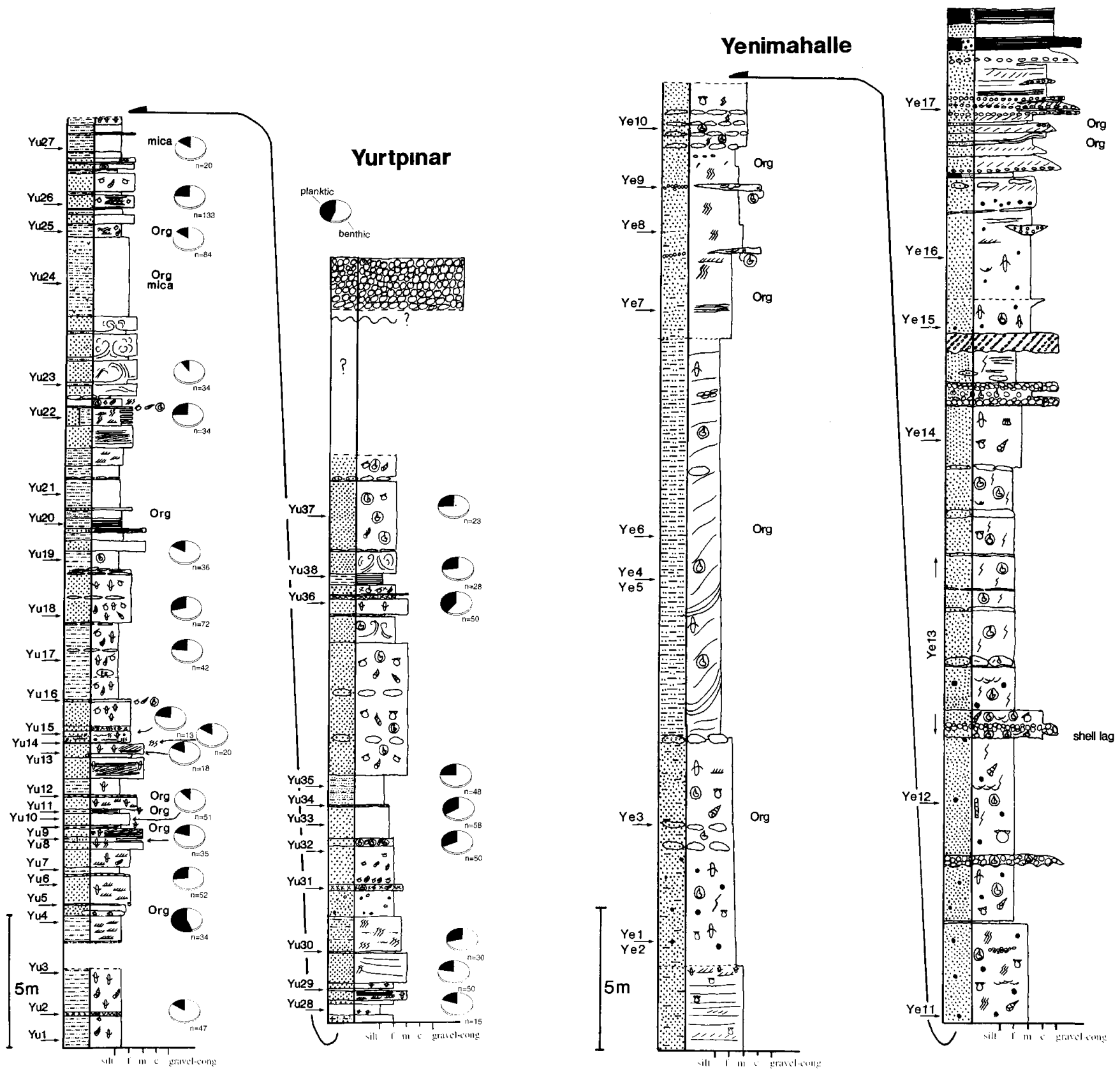

Fig. 7. Sedimentary logs of Pliocene successions at Yurtpinar (stream section) and Yenimahalle (along the road from Aksu to Isparta). See Fig. 3 for locations. Samples marked on the left-hand sides of the logs were used mainly for dating, foraminiferal environmental analysis and petrographic study.

\section{Northern fluvial conglomerates}

In the northernmost part of the Pliocene Aksu Basin, blue-grey siltstones, correlated with the lower part of the Yenimahalle Formation, are unconformably overlain by channelized conglomerates, up to $20 \mathrm{~m}$ thick. Akay \& Uysal (1985) mapped this interval as basal conglomerates of their Pliocene Eskiköy formation. However, an unconformable contact between the Pliocene and the overlying conglomerates is clearly exposed in a new road cutting along the Aksu-Isparta road, allowing correlation with the Çalkaya Formation. The base of this unit is highly eroded and contains intra-conglomerate erosional channels. Conglomerates are generally massive or horizontally stratified, with local cross-stratification, thin sand lenses and, locally (along the Aksu-Isparta road north of Yenimahalle), large rip-up clasts and 'rafts' of Pliocene marl. The conglomerates are interpreted as proximal braided-stream deposits (Miall 1978; Rust 1978). Associated horizontally bedded, massive gravels show some imbrication and are interpreted as longitudinal bars, lag deposits and sieve deposits, while crossstratified deposits are interpreted as channel fills and possible linguoid bars. Thin sandstone lenses were deposited in small areas of lower flow regime conditions.

At the point of emergence of the Aksu River onto the Antalya plateau the conglomerates reach $50 \mathrm{~m}$ in thickness and have a relatively steep primary dip $\left(25^{\circ} \mathrm{W}\right)$, indicating classification as fanglomerates (Nemec 1990). This deposit 
Table 1. Summary of benthic foraminifera found in the Manavgat and Yurtpinar successions

\begin{tabular}{|c|c|c|c|c|c|c|c|c|c|c|c|c|c|c|c|c|c|c|c|c|c|c|c|c|c|c|c|c|c|c|c|c|c|c|c|c|c|c|c|c|c|}
\hline & $\bar{z}$ & $\mid \frac{1}{2}$ & I & $\frac{\vec{z}}{\Sigma}$ & : & 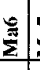 & $\frac{5}{\Sigma}$ & $\frac{\infty}{\sum_{0}^{\infty}}$ & हे & 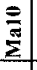 & $\frac{1}{2}$ & $\frac{2}{3}$ & 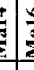 & 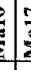 & $=$ & 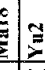 & 3 & \pm & 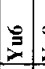 & $\stackrel{\infty}{\Xi}$ & $\stackrel{\Xi}{\Xi}$ & 3 & \pm & $\frac{5}{3}$ & $\vdots$ & \begin{tabular}{|c|c|}
$\infty$ \\
$\vdots$ \\
\end{tabular} & 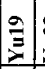 & สิด & 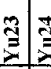 & $\frac{9}{3}$ & II & 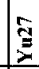 & 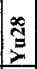 & 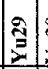 & 를 & $\widehat{\mathscr{z}}$ & $\frac{2}{3}$ & 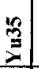 & \begin{tabular}{|c|c}
0 \\
$\vdots$ \\
$\vdots$
\end{tabular} & & 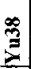 \\
\hline Ammonia & & & & & & & & & & & & & & & & $x$ & $x$ & & $x$ & $x$ & $x$ & $x$ & $x$ & $x$ & $x$ & $x$ & $x$ & & \begin{tabular}{c|c}
$x$ \\
$x$
\end{tabular} & $x \times$ & $x$ & & $x$ & $x>$ & $x$ & $x$ & $x$ & $x$ & $x$ & $x$ & $x$ \\
\hline Planorbulina & & & & & & & & & & & & & & & & & & $x$ & & & & & & & \begin{tabular}{|l|l} 
\\
\end{tabular} & $x$ & $x$ & & & & $x$ & & & $x$ & & 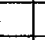 & 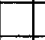 & & - & & \\
\hline Elphidium (keeled) & & & & & & & & & & & & & & & & & & & & & $x$ & $x$ & & & $\mathrm{x}$ & $x$ & $x$ & & $\bar{x}$ & $x$ & $x$ & $x$ & & $x$ & & $x$ & $x$ & & $x$ & & $\bar{x}$ \\
\hline Patellina & & & & & & & & & & & & & & & & $x$ & & & $x$ & & & & & & & $x$ & & $x$ & & & $x$ & & & & 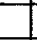 & 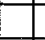 & 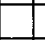 & & 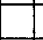 & $x$ & \\
\hline Nonion & & & & & & $x$ & $x$ & & & & & & & & & $x$ & & $x$ & $x$ & $x \mid$ & $x$ & $x$ & & $x$ & $x$ & $x$ & & $x$ & & $x$ & $x$ & & & $x$ & $\bar{x}$ & $x$ & $x$ & & $x$ & $x$ & \\
\hline Nummulites & & & & & & & & & & & & & & & & & & & & & & & & & $\mathrm{x}$ & & & & & & $x$ & & & & & 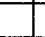 & & & & & \\
\hline Cancris & & & & & & & & & & & & & & & & & & & & & & & & & & $x$ & $x$ & & $x$ & $x$ & $x$ & & & & $x$ & $x$ & $x$ & $x$ & $x$ & & \\
\hline Elphidium (non keeled) & & & & & & & & & & & & \begin{tabular}{l|l}
$x$ & $>$ \\
\end{tabular} & $x$ & & & $x$ & $x$ & & $x$ & & $\bar{x}$ & & & $x$ & $x$ & $x$ & & $x$ & & $\bar{x}$ & $\bar{x}$ & & $x$ & & $x$ & $x$ & $x$ & $x$ & & $x$ & $x$ \\
\hline Quinqueloctlina & & & & & & & & & & & & & & & & $\bar{x}$ & & & $x$ & & & 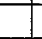 & & & & ( & & & $x$ & $\bar{x}$ & & $x$ & & $x$ & & + & 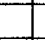 & & & & \\
\hline Neoconorbina & & & & & & & & $x$ & & & & 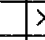 & $x$ & & & 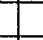 & & $\mathrm{x}$ & $x$ & $x$ & & $x$ & $x$ & & & $x$ & $x$ & & $x$ & $\bar{x}$ & $x$ & $x$ & $x$ & $x \mid$ & $x$ & $x$ & $x$ & $x$ & $x$ & & \\
\hline Honzawaia & & & & & & & & & & & & & & & & $\bar{x}$ & & & $x$ & & & & & & & & $x$ & & & & $x$ & & & & & 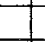 & & & & & \\
\hline Pyrgo & & & & & & & & & & & & & & & & & & & & & & & & & & & & & & & $x$ & & & & & 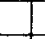 & & & & & \\
\hline Eggerella & & & & & & & & & & & & & & & & & & $x$ & & & & & & & & & & & & & & & & & & & & & & & \\
\hline Honnesia & & & & & & & & & & & & & & & & & & $x$ & $\times$ & $x$ & & $x$ & $\bar{x}$ & & & $x$ & $x$ & $x$ & & $x$ & $x$ & & $x$ & $x$ & $x$ & & & & $x$ & $x$ & \\
\hline Cibicides & $x$ & $\mathrm{x}$ & $x$ & $x$ & $\times 1$ & \begin{tabular}{l|l}
$x$ & 1 \\
\end{tabular} & $x$ & & & $x$ & \begin{tabular}{|l|l}
$\times 1$ \\
\end{tabular} & \begin{tabular}{l|l}
$x$ & $x$ \\
\end{tabular} & $x$ & 5 & & $x$ & & $x$ & $x$ & $x$ & $x$ & $x$ & $x$ & $x$ & $x$ & $x$ & $x$ & \begin{tabular}{l|l}
$x$ & $>$ \\
\end{tabular} & $x$ & $x$ & $x$ & $x$ & $x$ & $x$ & $x$ & $\times 1$ & $x$ & $x$ & $x$ & & $\bar{x}$ \\
\hline Firsenkonia & & & & & & & & & & & & & & & & & & & & & & $x$ & & & & $x$ & & & & $x$ & & $x$ & $x$ & $x$ & & 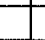 & & & $x$ & & \\
\hline Brizalina & & & & & $x$ & & & $\bar{x}$ & $\bar{x}$ & & & & & & $x$ & $x$ & & & & $x$ & & & & & & & & $\times$ & & $x$ & $x$ & & & & & $x$ & & & & & \\
\hline Bulimina & $x$ & & & $x$ & \begin{tabular}{l|l}
$x$ & \\
\end{tabular} & 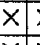 & $\bar{x}$ & $x$ & & & \begin{tabular}{l|l}
$x$ \\
\end{tabular} & \begin{tabular}{l|l}
$x$ & $x$ \\
\end{tabular} & & & $4 x$ & $\bar{x}$ & & & & & & 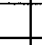 & & & & 1 & & $x$ & & $x$ & $x$ & & & $x$ & & & $x$ & $x$ & & & \\
\hline Bolivina & & & $x$ & & & \begin{tabular}{l|l}
$x$ \\
\end{tabular} & $\bar{x}$ & $x$ & & & $x$ & & $\lambda$ & & $x$ & $x$ & & $x$ & & $\times \mid>$ & $x$ & $x$ & & & $x$ & $x$ & $x$ & \begin{tabular}{l|l}
$x$ & $>$ \\
\end{tabular} & $\bar{x}$ & $x$ & $x$ & $x$ & $x$ & $x$ & & $\times 1$ & $x$ & $x$ & & $\times$ & $x$ \\
\hline Triforina & $x$ & $x$ & $x$ & & & & & & & & & & & & & & & & $x$ & & & & & & & & & & & & & & & & & & & & & & \\
\hline Textularia & & & & & & & & & & & & & & & & & & & & & & & & & & $x$ & & & & $\bar{x}$ & $x$ & & & & & & $x$ & & $x$ & & \\
\hline Melonis & & & & & $x$ & \begin{tabular}{l|l}
$x$ \\
\end{tabular} & $x$ & & $x$ & & & \begin{tabular}{l|l}
$x$ \\
\end{tabular} & & & & & & & & & & & & $x$ & & $x$ & $\times$ & $\times \mid>$ & $x \mid x$ & $x$ & $x$ & $x$ & $x$ & $x$ & & & & & $x$ & $x$ & $x$ \\
\hline Plamulina & $x$ & $x$ & $x$ & & $x$ & \begin{tabular}{l|l}
$x$ \\
\end{tabular} & & & & & & & & & & & & & & & & & & & & & & & & & & & & & & & & & & & \\
\hline Globocassidulina & $x$ & & & $x$ & & & $x$ & & & & & & & & & & & & & & & & $x$ & & & & & $\bar{x}$ & & & & & & & & & & & & & \\
\hline Uvigering & & $x$ & $x$ & $\mathrm{x}$ & & & $x$ & & $x$ & & & & & 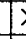 & 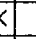 & $x$ & & & & $x \mid>$ & $x$ & $x$ & $x$ & & $x$ & & & & & & & & & & & $x$ & & & & $\bar{x}$ & \\
\hline Lenticulina & $x$ & & & $\mathrm{x}$ & $\mathrm{x}$ & $x$ & $\times$ & & & $\bar{x}$ & & & & & & & & & & & & & & & & & & & & & & & & & & $x$ & & & & & \\
\hline Pullenia & & & $x$ & & $x$ & & $\bar{x}$ & & & & & & & & & & & & & & & & & & & & & & & & & & & & & & & & & & \\
\hline Karreriella & & & & $x$ & $x$ & & & & & & & & & & 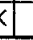 & & & $\times \mid$ & & & & & & & & & & & & & & & & & & & & & & & \\
\hline
\end{tabular}

The samples are listed from bottom to top, Manavgat succession and then Yurtpinar succession. Benthic foraminifera are arranged in approximate order of water depth in which they live. The presence of a particular genus in a sample is marked by a cross. The results indicate that the Manavgat succession includes a deeper-water assemblage than the Yurtpinar succession.
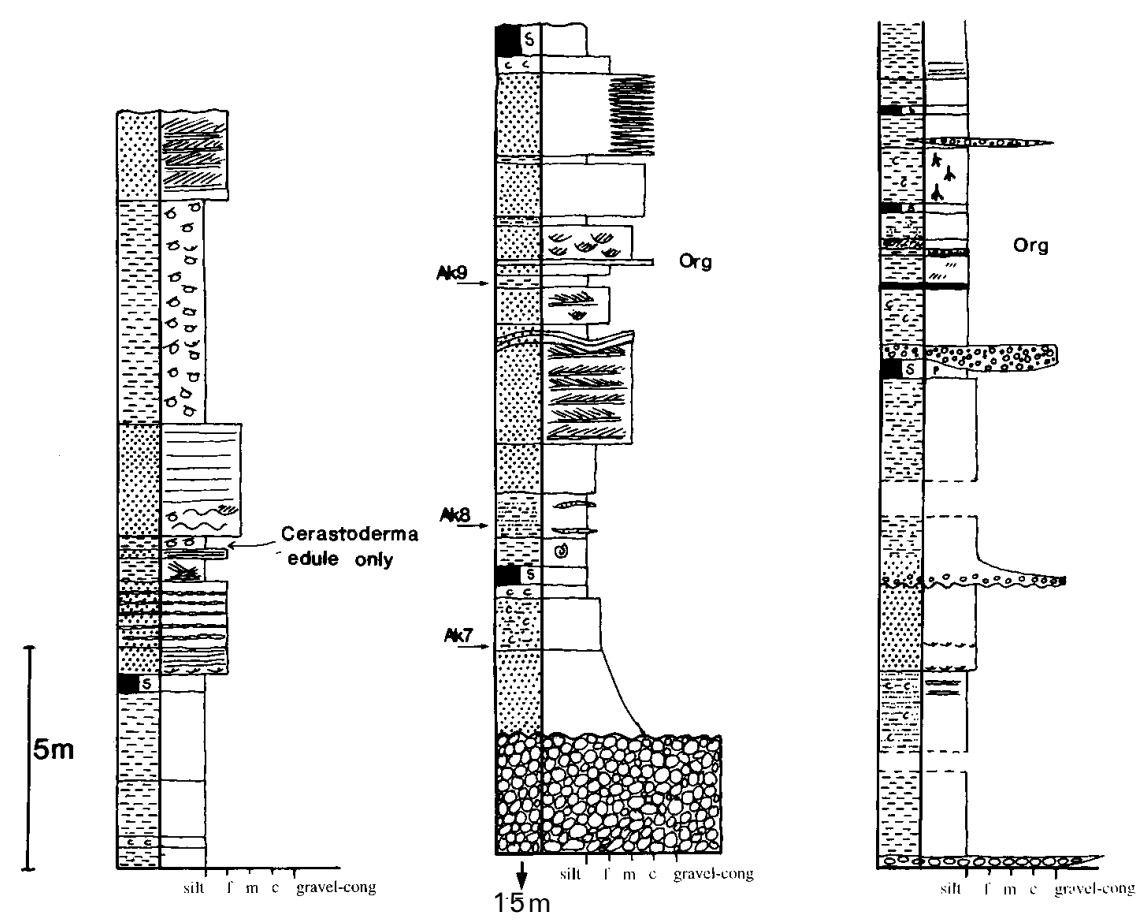

Fig. 8. Logs of Pliocene succession on the southern part of the Aksu Basin (Çalkaya Formation), near Aksu village. These logs were measured in fresh road cuttings during construction of the bridge just west of Aksu, now covered with concrete; see Fig. 3 for locations. 


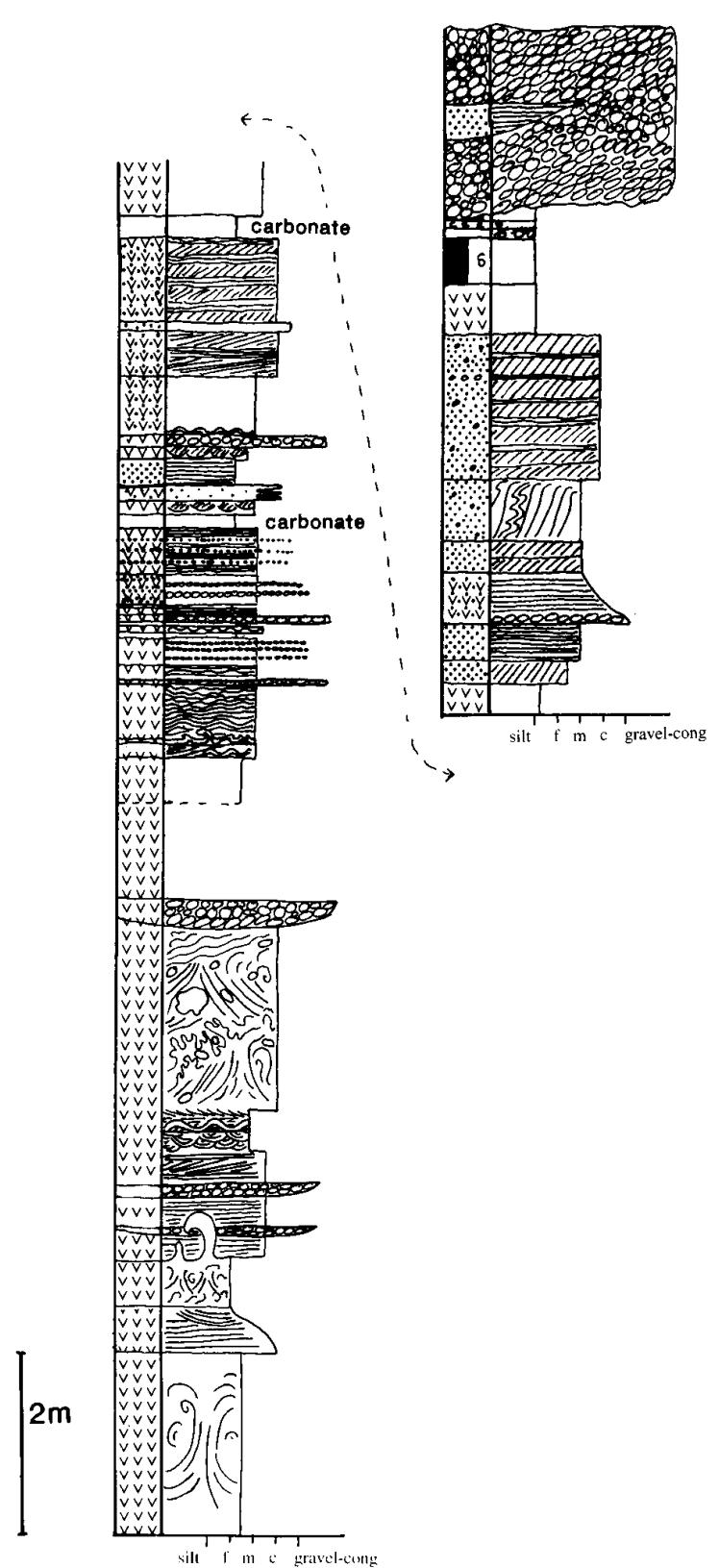

Fig. 9. Log of the Pliocene Çalkaya tuff, near Çalkaya; see Fig. 3 for location.

is limited in extent and shows no evidence of significant mass-flow type deposition.

\section{Volcaniclastic unit}

A homogeneous tuff deposit, c. $10 \mathrm{~m}$ thick, occurs locally within the Aksu Basin, near Çalkaya village. This unit grades into tuffaceous sandstone and then into conglomerate (Fig. 9). Bedding is planar, low-angle cross-bedded, wavy or trough cross-bedded, and is defined by sorting into mafic and felsic mineral laminae. Planar bedding, symmetrical ripples, trough cross-beds, low-angle cross-bedding and convolute bedding/ flame structures are all common. Pumice clasts are ubiquitous and locally form channel-fill deposits. Towards the top of the succession, a palaeosol horizon and a shell bed are both present. Pumice and the tuffaceous sediment clasts contain unaltered biotite, green pyroxene, alkali feldspar, plagioclase feldspar, amphibole, sphene, zircon, quartz and opaque minerals with, in addition, some lithic fragments (mainly mudstone) and carbonate grains. The groundmass of the pumice is trachytic, with small laths of plagioclase (with domains of preferred orientation) set in a dark, glassy matrix. Predominant alkali feldspar phenocrysts show concentric and random zonation and occur with biotite.

A channel filled with tuffaceous material and pumice pebbles locally cuts down into a sandy soil layer, further north, in the Yeşilkaraman region (Fig. 3). A gravelly point bar can clearly be distinguished at the edge of the channel. A tuffaceous bed is also observed nearby. The pumice pebbles are petrographically similar to those of the Çalkaya area and contain zoned feldspars and biotite phenocrysts in a trachytic groundmass.

$\mathrm{X}$-ray fluorescence analysis of both the pumice and the tuff from the Çalkaya area indicates a trachytic composition (Glover 1995). Özgür et al. (1990) identified trachytes around Isparta as late-stage products of coeval alkalic eruptions. Explosive pyroclastic eruptions are anticipated with this magma composition (Fisher \& Schminke 1984). The Çalkaya tuff is interpreted as a basal surge deposit of small, shallow phreatomagmatic eruption (i.e. a tuff-ring). This is envisaged as only a few hundred metres across, located in the vicinity of Çalkaya. No evidence of the actual vent was found. The impure Yeşilkaraman tuff is thought to be the result of reworking of a similar tuff-ring into a clastic channel, together with other sediment. This is consistent with the interpretation of an ignimbrite near Isparta as a maar deposit (Lefèvre $e t$ al. 1983).

\section{Depositional processes of the Pliocene basinal units}

The Yenimahalle Formation is interpreted as a fine-grained shallow-marine shelf deposit, within a low-gradient system characterized by a low bedload/total load ratio. Reworking of nanoplankton, but not of foraminifera, also suggests a relatively quiet depositional setting. Blue-grey siltstones and sandstones, also crop out in the very north of the area, indicating that there was no significant supply of coarse-grained material even in the most proximal part of the basin. A grid of five offshore seismic lines across Antalya Bay are interpreted as follows: A deltaic package with clear onlap of sediments onto sequence boundaries sits above a bright reflective surface interpreted as Messinian evaporites. There is no well control, but using an interval velocity of $1000 \mathrm{~m} \mathrm{~s}^{-1}$ the package suggests that Pliocene sediments $500 \mathrm{~m}$ thick were deposited.

Benthic foraminifera species, the absence of rotalid planktic foraminifera and the small size of all foraminifera, taken together, indicate a water depth of $<150 \mathrm{~m}$. The sequence shallows-up gradually and foraminifera, macrofauna and trace fossils of the Yurtpinar and Yenimahalle successions indicate water depths of $<50 \mathrm{~m}$ for a significant period. Local, small phreatomagmatic eruptions occasionally deposited tuffaceous sediment in horizons subjected to variable reworking. At the end of a well-documented Pliocene highstand, rapid climatic cooling and onset of Mediterranean wide Arctic glaciation then resulted in a large sea-level drop (Wornardt \& Vail 1991). This probably terminated marine deposition in the Aksu Basin. This interpretation is supported by the presence of planktic foraminifera that date the onshore Yenimahalle Formation as Late Zanclean (Globorotalia puncticulataGloborotalia margaritae zone; Glover 1995) and the Çalkaya 
Formation as nannofossil zone NN14/15 (C. Müller pers. comm. 1995).

An ensuing rapid regressive phase then resulted in deposition of the coarse-grained Çalkaya Formation in a shallow-water deltaic system. A small, coarse alluvial fan developed at the emergence point of the Aksu River. This dissects an earlier fanglomerate of the Miocene Aksu Formation, suggesting that the emergence point of the Aksu River has remained little changed at least since the Mid-Miocene, despite the intervening Late Miocene salinity crisis. The fan shallows into braid-plain sediments that eroded into the underlying marine sediments of the Yenimahalle Formation. Southward progradation of the braid plain is not observed, suggesting that the fluvial regression was sufficiently rapid that the river system was unable to keep pace with a retreating shoreline. A sandy, wave-influenced, delta-top environment, instead, covered most of the southern basin area. A lowgradient shoal-water type setting is envisaged, as Gilbert-type foresets are not seen (Postma 1990). Assuming a coastline approximately parallel to today, the larger conglomerate bodies are interpreted as longitudinal bars, possibly mouth bars along a wave-influenced fluvial delta distributary front. The coals are interpreted as the product of significant periods of subaerial exposure on stable bars. Isolated patches of marine, brackish, or freshwater may have remained for some time in this environment, leading to deposition of draping clays, carbonates and restricted fossil assemblages. Very localized faulting in the Aksu Basin is interpreted as of synsedimentary origin, perhaps influenced by delta morphology and triggered by seismic shocks.

\section{Coastal fanglomerates}

The coastal road southwest of Antalya cuts through a number of fanglomerate units. These are separate lobes spaced at regular intervals along the coast (c. $2-5 \mathrm{~km}$ apart). Two conglomerate facies are present. The most common is clastsupported and contains angular-subangular clasts, ranging from a few centimetres to tens of centimetres. Bedding occurs on a metre scale; some of the less coarse beds display low-angle cross bedding. Logging of the lower part of a typical large fan near Phaselis (Fig. 10) shows that the majority of these deposits consist of bedded conglomerate. Beds vary in degree of sorting and clast size, but are not chaotic. The second conglomerate facies is extremely poorly sorted, matrix supported and contains angular clasts, up to $3 \mathrm{~m}$ in size (Fig. 11). The first facies is interpreted as a steep alluvial fan, whilst the second is viewed as a debris-flow deposit (Nemec \& Steel 1984; Nemec 1990).

The Kemer Fanglomerates are interpreted as a series of small coarse-grained fan deltas that were shed from steep scarps, created by extensional faulting of the Tauride Mountains to the west. Deposition took place principally on steep alluvial fans, with occasional deposition from debris flows. The Kemer Fanglomerates can be compared with similar, but better exposed, deposits for example in the Gulf of Elat (Gvirtzman \& Buchbinder 1978), or southern Crete (Nemec \& Postma 1993).

\section{Antalya Tufa}

The tufa deposits of the Antalya region occupy c. $600 \mathrm{~km}^{2}$ of the northwestern part of the Aksu Basin, being up to $250 \mathrm{~m}$

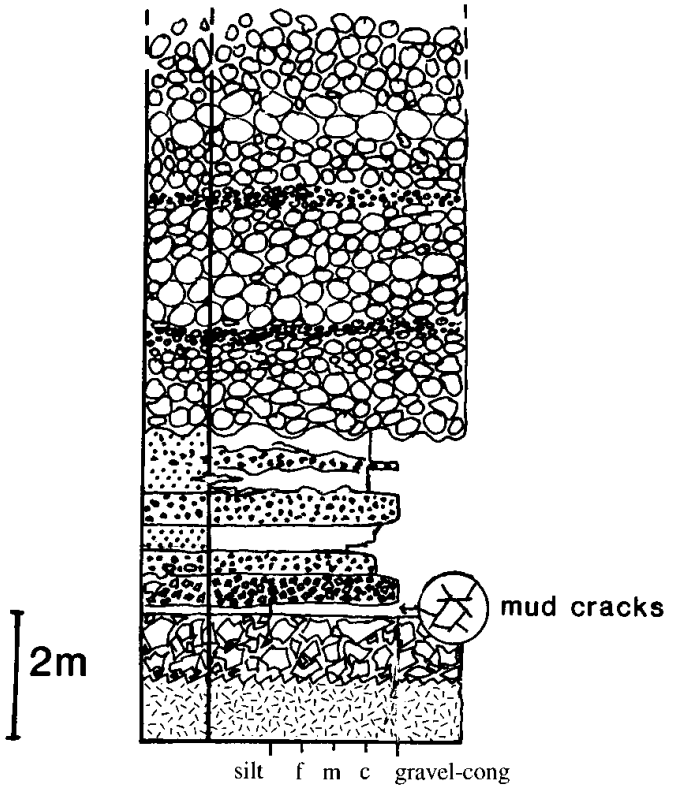

Fig. 10. Log of the succession in the lower part of a fan delta at Phaselis along the coast, SW of Antalya. The conglomerates continue upwards for a further $25 \mathrm{~m}$, but were too high to measure. See Fig. 16 for location.

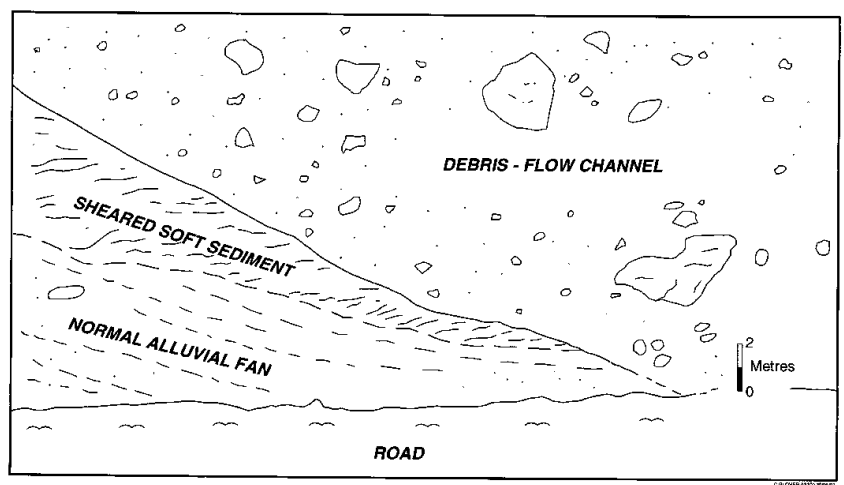

Fig. 11. Sketch to show chaotic facies cut into well-bedded facies. The chaotic facies is interpreted as a debris flow deposit, while the underlying unit is part of a normal alluvial fan. A pale band between the two facies is seen as a sheared layer resulting from the force of the down-cutting debris flow above. Kemer Fanglomerate, near Kemer (opposite 'rat' island).

thick in the west and 20-30 m thick in the east. The tufa crops out as a series of major terraces that dominate the present-day landscape (Fig. 5). The origin of the tufa is now relatively well understood (Planhol 1956; Burger 1990, 1992; Özüs 1992) and can be summarized as follows. Extensive karst systems, developed within the Mesozoic carbonates of the adjacent Taurus Mountains. These supplied large volumes of carbonatesupersaturated waters, primarily at Kırkgöz (i.e. forty springs), situated in the northwest part of the Aksu Basin. The waters originated from lakes up to $100 \mathrm{~km}$ to the north, and from a now dry 'polje' system further south (at Kestel, Fig. 5).

The vast majority of tufa seen in the Antalya area consists of horizontally-bedded carbonate-dominated sediments that can be subdivided into a number of facies, following the work of Pedley (1990). Local environments of deposition can be determined for individual facies taking account of variables, 


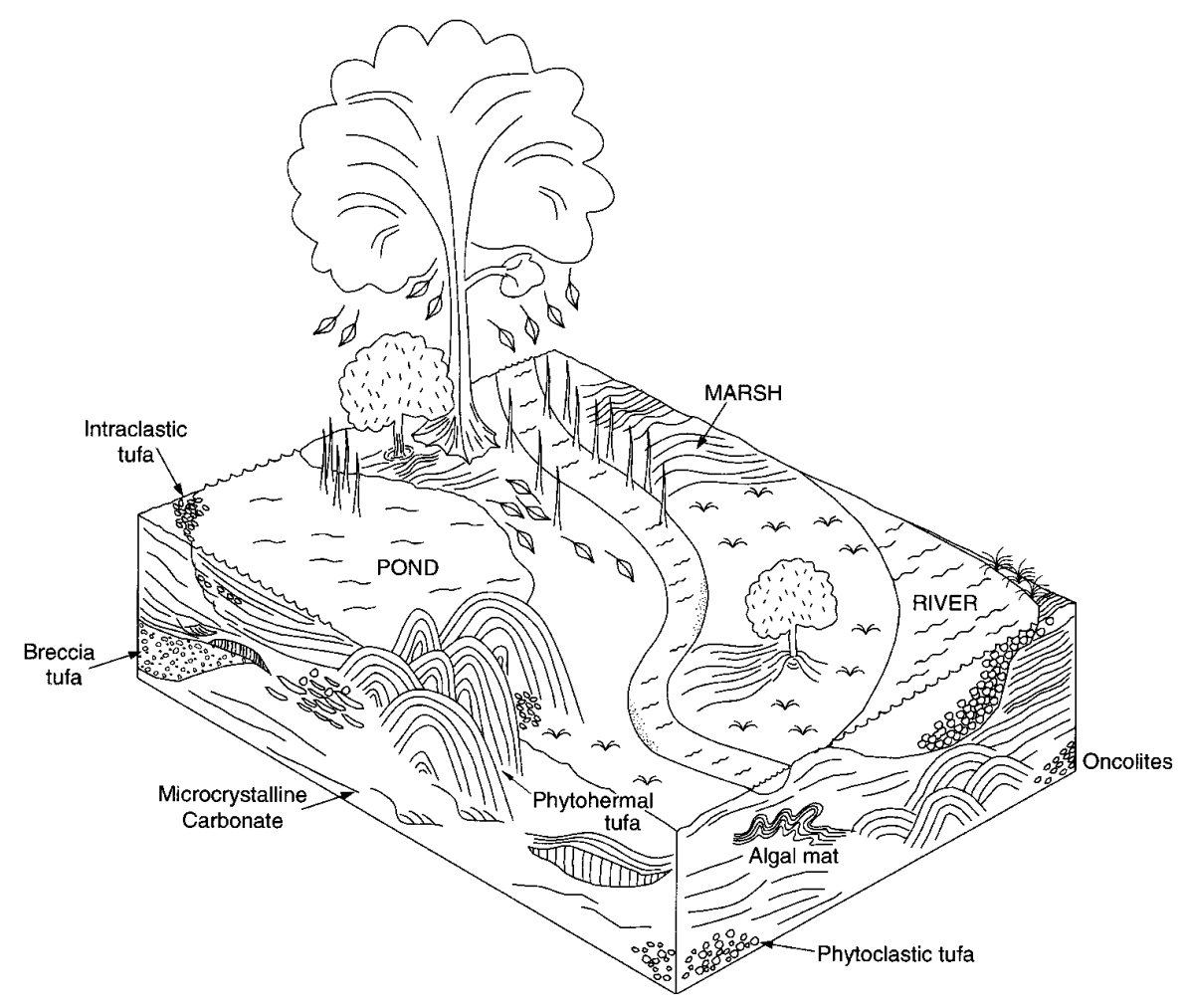

Fig. 12. Model of Antalya tufa deposition. Carbonate-charged groundwater is released from springs, resulting in tufa precipitation in a range of fluvial, paludal and lacustrine settings (i.e. marked as RIVER, MARSH \& POND). including water depth, energy of environment, dominant flora and fauna, and this, in turn, allows an overall depositional model for the entire deposit to be developed (Fig. 12).

In outline, the initial tufa deposits are clay-rich microcrystalline carbonates, rich in gastropods. Clasts of peridotite occur within the deposit where it is in direct contact with Mesozoic basement, towards the western margin of the basin. The sediments in this area grade upward into pure microcrystalline tufa, with regular interbedded carbonaterich palaeosols. These pure microcrystalline tufas dominate the succession for about $10 \mathrm{~m}$ and then the sediments become more varied, with localized lateral and vertical facies transitions. All facies types are present at this level and shallowerwater and paludal-type deposits are incised by channels, which deposit tufa breccia. The top $10 \mathrm{~m}$ of the succession differs, as it consists almost entirely of phytoclast tufa.

Initially, the tufa was probably limited to deposition in small lakes interspersed with soil formation as climate fluctuated. A cluster of springs near the present Kirkgöz (Fig. 5) is one probable source, but a more widespread series of springs probably existed. On the eastern basin margin, primary deposition was dominantly algal, perhaps reflecting the presence of a localized shallow 'lagoon' in close proximity to source waters. With time, any pre-existing palaeotopography was progressively infilled and a broader zone of tufa deposition developed. This represents the main phase of tufa deposition. The overlying, predominantly phytoclast and phytoherm, deposits of the uppermost $20 \mathrm{~m}$ then formed when springwater supply was reduced, probably during a time of drier climate. A pre-400 000 years age for the Antalya tufa is suggested by U-Th dating (i.e. an age beyond the maximum age resolution of the method). This is consistent with the floral assemblages present. However, on the current evidence, the absolute age of the tufa remains uncertain.

There is no evidence for cyclicity within the Antalya tufa deposit and no intraformational karstification is seen. Depo- sition possibly occurred during one climatic period. Much of the preserved flora (i.e. Lonicera sp., Viburnum sp., Alnus glutinosa; G. Schweigert pers. comm. 1994) would have thrived in a climate that was cooler and damper than at present. The presence of Parrotia persica in the assemblage further suggests that the bulk of deposition occurred before the onset of the glacial period. The relict form Alnus glutinosa also confirms that the tufa is not modern (Meusel et al. 1965).

Significant deposition of tufa probably ceased prior to the Mid-Pleistocene. Glacials were too cold and wet, while interglacials were too arid for extensive tufa formation (Marker 1971; Pedley 1990). Instead, late erosion resulted in well developed terracing of the Antalya plain (Fig. 5). Subsequent depositional modification of these terraces has taken place until the present time, producing a thin veneer of slope pools, waterfall deposits and terrace mound deposits in localized areas. This effect also explains why some previous radiometric dating has yielded anomalously young ages for the tufa (Burger 1990, 1992). Tufa deposition today is very limited, despite continued emergence of highly supersaturated spring waters (i.e. at Kirkgöz). Minor deposition mainly occurs in highly turbulent waterfalls and small streams. Fine carbonates also precipitate at source springs and areas of ephemeral water supply, where algal mats remain after evaporation of shallow water.

The basis of the proposed depositional model (Fig. 13) is that the Aksu plain was dominated by paludal and lacustrine environments, with water depths ranging from centimetres to metres (possibly up to $20 \mathrm{~m}$ deep in local depressions). A number of small rivers $(5-10 \mathrm{~m}$ in width and probably meandering) and streams (1-2 $\mathrm{m}$ in width) wound their way across a relatively level alluvial plain, constantly reworking friable carbonate deposits through which they passed. The dominance of intraformational clasts and lack of detrital material within the fluvial deposits show that they were spring sourced and not run off from surrounding mountains. The situation appears to 


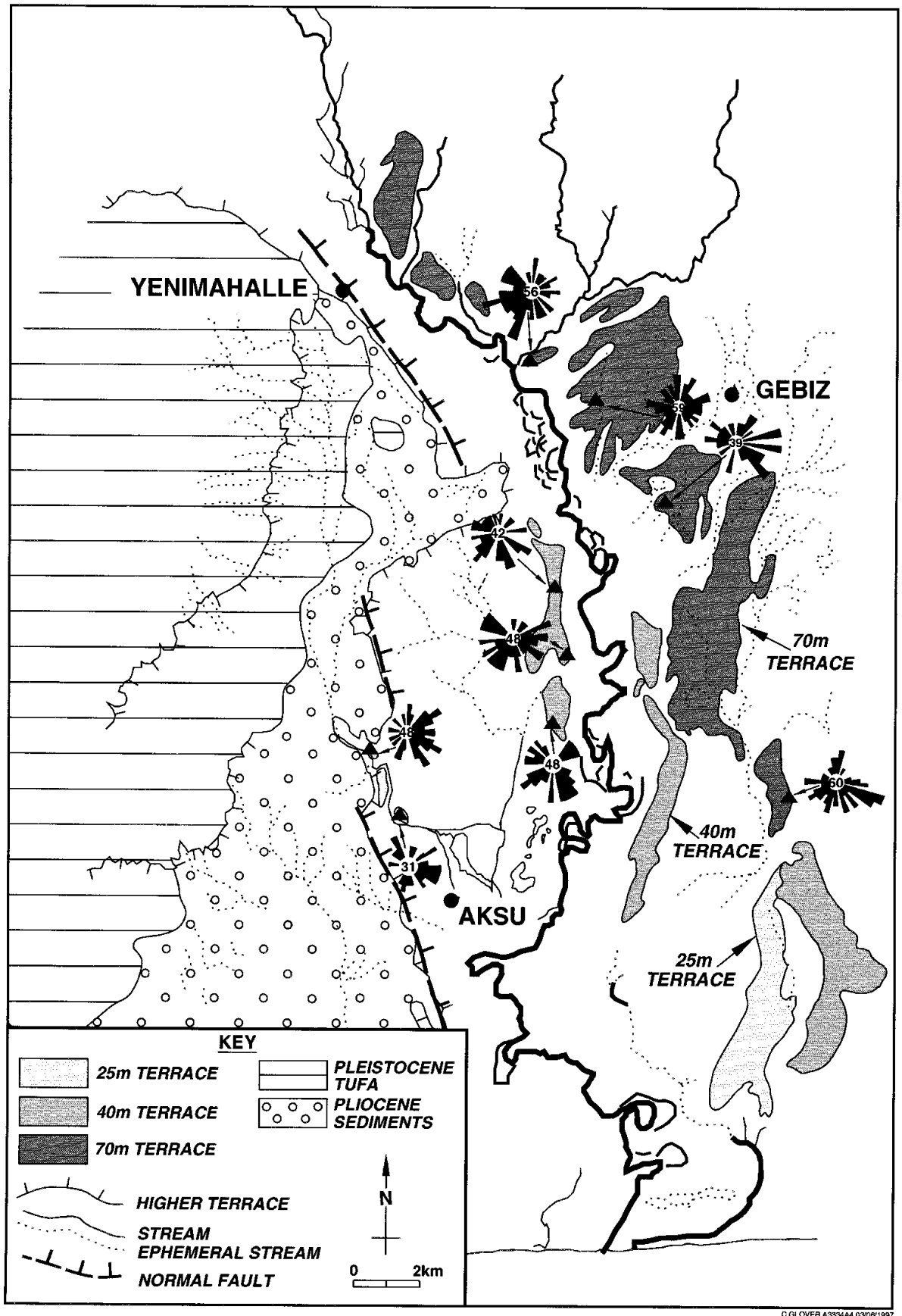

Fig. 13. Map of Pleistocene fluvial terraces in the Aksu River flood plain. Three terrace levels are recognized $(70 \mathrm{~m}$, $40 \mathrm{~m}$ and $25 \mathrm{~m}$ ). Palaeocurrents are from clast imbrication measurements; the number of counts is marked at the centre of each rose. Meander loops were identified using 1:25000 maps. The fault scarps and the tufa terraces pre-date the phase of the river's activity, and ephemeral streams on the upper terrace have subsequently cut back the tufa terrace during wetter periods. be a complex mix of that seen in the lacustrine and paludal environments of the Hula Valley, Israel (Heimann \& Sass 1989); the Tanagro Valley, Italy (Buccino et al. 1978); the Slakow graben, Poland (Szulc \& Cwizewicz 1988), and in a fluvial environment of central Spain (Ordóñez \& Garcia del Cura 1983).

\section{Pleistocene fluvial deposits}

Pleistocene river terrace deposits (i.e. Belkis Conglomerate, Fig. 13) are lithologically similar to underlying Pliocene conglomerates (i.e. Çalkaya Formation), but differ in location and distribution. They can mainly be distinguished by their localized extent and proximity to the present Aksu River.
Palaeocurrent data do not reveal any clear flow direction. The median clast size is $1-5 \mathrm{~cm}$ and the dominant clast type is Mesozoic limestone derived from the Antalya Complex. Clasts are well-rounded and the fabric is clast-supported, with a reddish matrix. Clasts of tufa are not observed, as the Aksu River avoids the tufa outcrop.

\section{Terra rossa-type palaeosols}

Remnants of a bright red terra rossa-type soil are observed in small pockets in the tufa surface throughout the area. The soils are primarily redeposited as steep-sided channels cut into the Pleistocene conglomerates and the edge of the tufa. Terra rossa is known to develop on a homogeneous limestone 


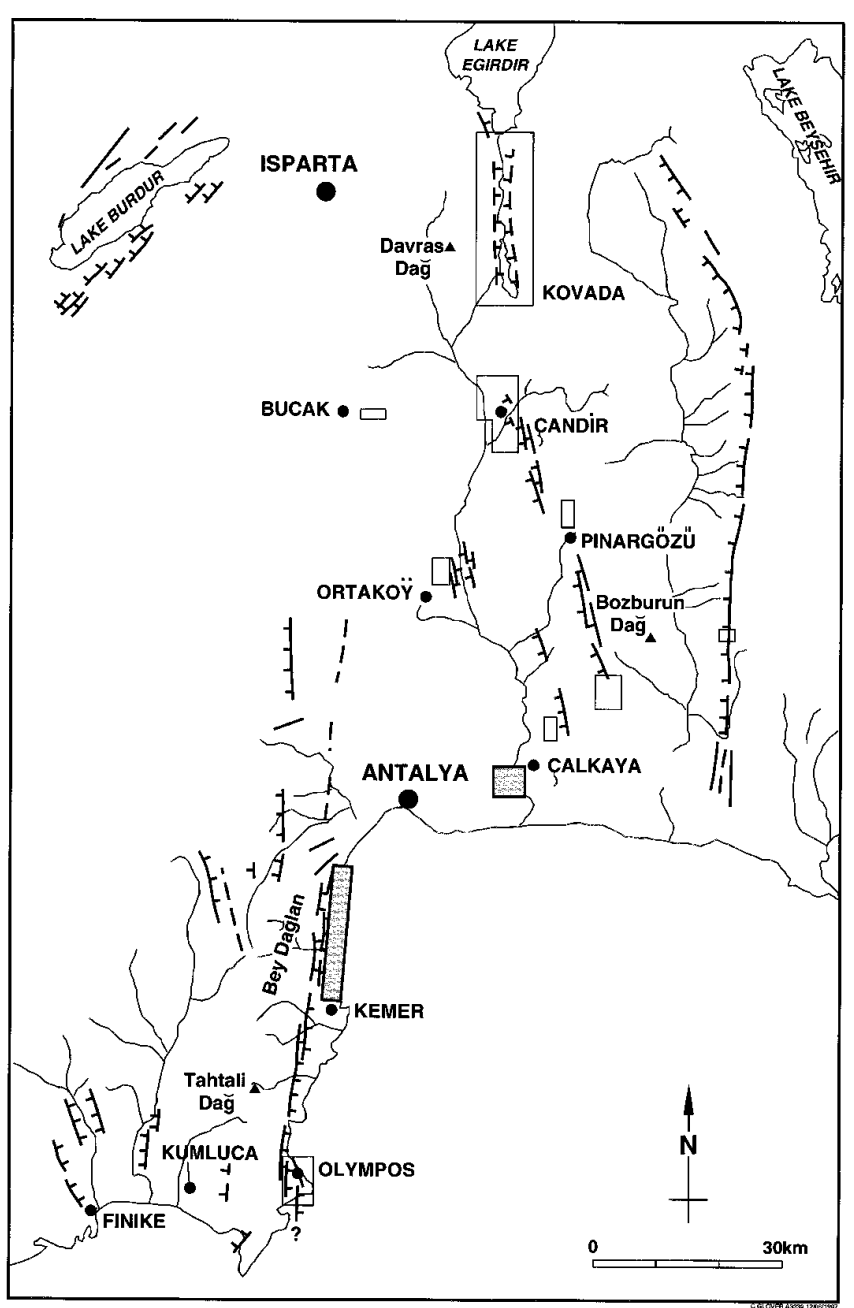

Fig. 14. Map of the Isparta Angle showing the main neotectonic lineaments, which can be identified, in the field and from satellite images. Boxes indicate areas where data on fault plane orientations were collected. The shaded boxes at Kemer and Çalkaya are the areas discussed here in detail.

substructure, and requires an extremely hot and dry summer climate to form. The soil is normally strongly decalcified and its vivid red colour results from the presence of water-deficient ferric hydroxide (Kubièna 1953). Burger (1992) noted that, despite a high iron content, the Antalya palaeosols are too depleted in carbonate, but enriched in foreign materials to be classed as an ideal terra rossa. Much of the Antalya terra rossa-type soils formed on an adjacent Mesozoic limestone basement, although some also developed on the tufa, as shown by the presence of complex solution hollows filled with red soil (e.g. in a quarry behind Yeșilkaraman, Fig. 3). Terra rossafilled channels are usually closely spaced (5 $\mathrm{m}$ apart), U-shaped features that are cut into Pleistocene fluvial conglomerates, but are locally also incised into Pliocene sediments (e.g. top of the logged Yenimahalle section). The channels were apparently cut and filled by catastrophic events, probably flash floods.

\section{Neotectonic features}

Steep scarps define strong lineaments in the Taurus Mountains, which can be mapped from the ground and are also visible on satellite images (Fig. 14). The most marked features are along the western edge of Antalya Bay, the Kirkkavak Fault on the eastern margin of the Köprü basin, and within the Taurus Mountains (e.g. around Çandır). Structural data were collected in these regions, and within Miocene and Pliocene sediments of the Aksu Basin. Large polished fault planes are very rare and measurements were made on meso-scale planes (few centimetres-few metres), often with only traces of slickenfibres remaining from which the sense of motion could be determined. Nearly 1000 measurements were taken, mostly from Mesozoic limestones. In contrast, kinematic indicators on fault planes in the Neogene sediments can only rarely be seen in freshly cut sections. Within unconsolidated Pliocene sediments, fault planes were often taken by sighting. Care was taken that the faults measured are truly neotectonic and not remnants of older tectonic features. The Late Pliocene Aksu Phase of compression tilted the Miocene sediments along the eastern margin to almost vertical and cross-cutting faults are clearly of post-Miocene age.

Field data from two representative areas a more complete database (Glover 1995) are discussed below.

\section{Western basin margin}

The coastal section from Antalya to Kemer is dominated by large neotectonic, normal fault scarps (Fig. 14). Unfortunately, these are mainly inaccessible. However, the fault scarps are highly eroded, with stepped and cavitated surfaces typical of degraded Mediterranean normal faults (Stewart \& Hancock 1989). Along the coastal section, the main road cuttings through limestones expose numerous fault scarps. 131 mesofault planes were measured, of which 77 had measurable kinematic indicators; a sense of movement was clear from 65 of these. Stereographic projection of directional data clearly indicate the existence of right-lateral faults running NE-SW and NW-SE (Fig. 15). A rose diagram of the data yield more scattered, but simpler patterns. In addition, normal faults cluster around a NNE-SSW direction.

One possibility is that the above fault patterns are entirely the result of oblique slip, compartmentalized into normal and strike slip components. This can, however, be ruled out as: (i) normal slickensides are widely seen to be superimposed on strike-slip ones; (ii) both normal and oblique fault indicators are locally present on the same NNE-SSW-trending fault planes; (iii) the scale of the individual normal faults (exposed fault planes $>300 \mathrm{~m})$ and vertical relief $(>1000 \mathrm{~m}$ above sea level) of the fault lineaments as a whole show that normal faulting dominates in the landscape of the present time.

Two phases of faulting are thus recognized. An early phase of right-lateral faulting had a strong oblique-slip component, split into two orthogonal fault directions (NE-SW and NW$\mathrm{SE}$ ) and may have resulted from $\mathrm{N}-\mathrm{S}$ extension that was oblique to pre-existing basement structures. In the current study, plots of dip versus pitch of strike-slip faults show that those assigned to a normal origin have only a small oblique component. The same normal faults also tend to have relatively constrained orientations, often bisecting strike-slip directions, and suggesting that the stress field may have been relatively orthogonal during the period of normal faulting. It is, thus, possible that the change from dominantly strike-slip to dominantly normal faulting represents a change from N-S extension oblique to pre-existing structural lineaments, to NE-SW extension, orthogonal to structural lineaments. 

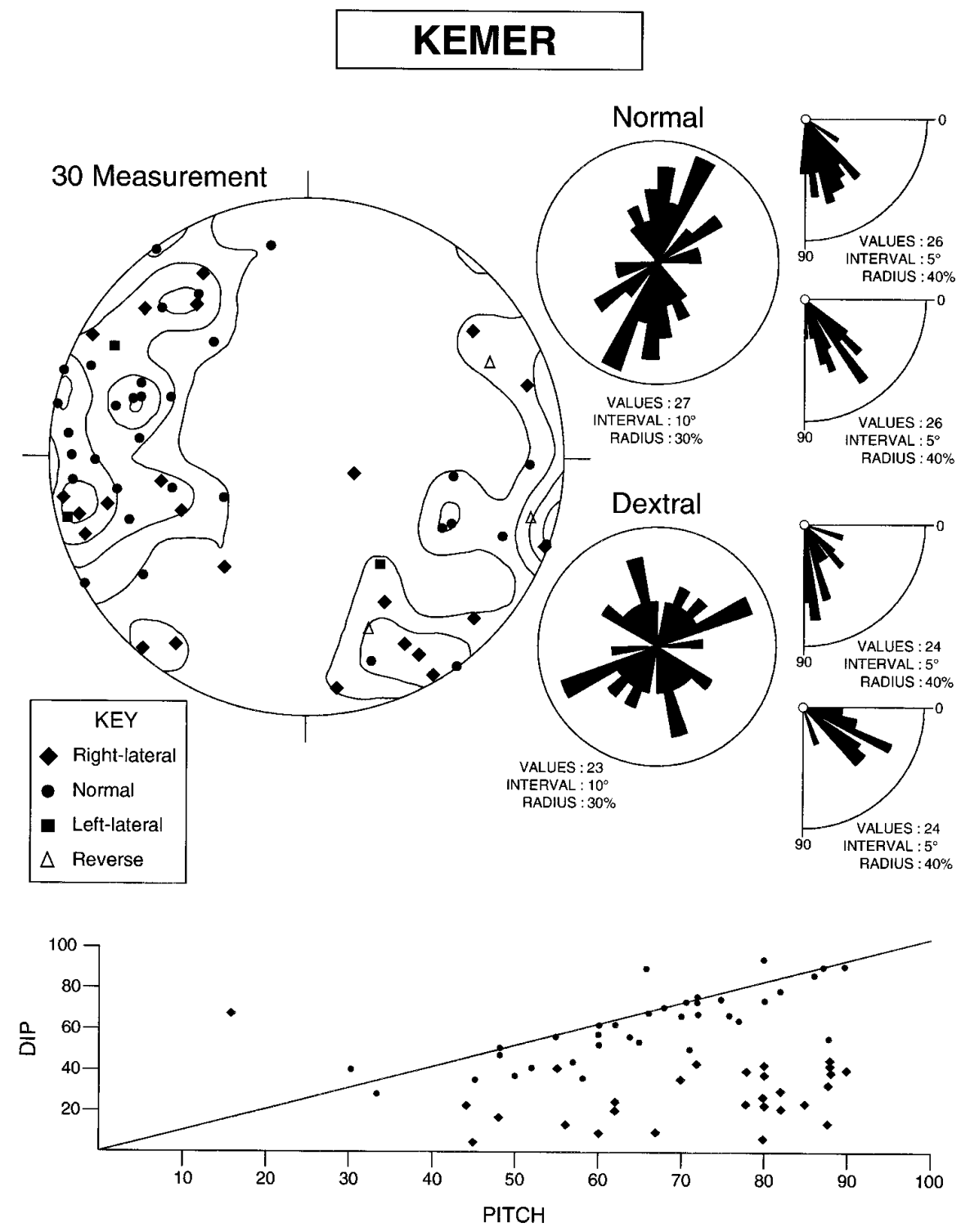

Fig. 15. Fault plane orientation data from the Kemer area: Stereographic projection of poles to fault planes with known direction indicated by symbols, normal faults indicated by dots reverse faults by open triangles and right- and left-lateral faults by diamonds and squares respectively. The rose diagrams are of fault data divided by fault class (normal and right-lateral). For each the main rose is of fault plane strike (non-directional); the upper quarter plot represents the fault plane dip direction and the lower quarter plot the pitch of slickensides. The scatter plot of dip versus pitch of the faults also shows the relationship between fault plane and slip direction. The straight line represents the plot of pure dip-slip faults. The data indicate a clear distinction between normal and right-lateral faults.
Remnants of mature slope surfaces are present along the entire western edge of the Aksu Basin. The smooth, evenly sloping surfaces must have developed over a substantial time period. The Antalya tufa covers these erosion surfaces, suggesting that they were well developed by the Late Pliocene/early Pleistocene. Such slope remnants increase in size and frequency southwards, and occur up to an altitude of $c .3000 \mathrm{~m}$, about half the total height of the adjacent mountains (e.g. Tahtal Dağ). The surfaces are developed above the Kemer fanglomerates on the lower slopes and as smooth erosion surfaces on the higher slopes. Similar surfaces, associated with 'capping breccias' are developed in the Kumluca region to the west of the study area (Woodcock \& Robertson 1982). The profile A-A' (Fig. 16), near Phaselis, is a good example. Well-developed soils exist on the upper surfaces of the fans, suggesting that the landscape was stable for a significant time period. These slopes are now heavily dissected by both faulting and by fluvial downcutting to create relatively immature slopes as at present, as shown by a series of sections perpendicular to section $\mathrm{A}-\mathrm{A}^{\prime}$. The fans plunge directly into Antalya Bay, with a small cliff developed at the present-day shoreline.

\section{Faults cutting Pliocene sediments}

Faults are also common in Pliocene sediments (around Çalkaya, Fig. 3, 14), but are very difficult to measure due to the unconsolidated nature of the sediment. Of 68 measurements only two kinematic indicators were found, both indicating normal faulting. A rose diagram and stereographic projection show a range of directions for faults in Pliocene sediments (Fig. 17). The only available kinematic data, shown on the stereographic projection, indicate that the NNE-SSW directions were the results of normal faulting. Some of E-W directions may relate to earlier syn-sedimentary faulting, as observed in the Aksu area. Some degree of cluster can be identified in NE-SW and NW-SE orientations.

The Pliocene sediments are typically tilted in a westerly direction, towards the main Kemer fault scarps. There is no evidence that movement occurred as the sediments were deposited. In the field, fault offsets are often small, but always imply a normal component. They are also nearly always single planes. If significant shear had affected the sediments, broader zones containing multiple strands of fault planes 

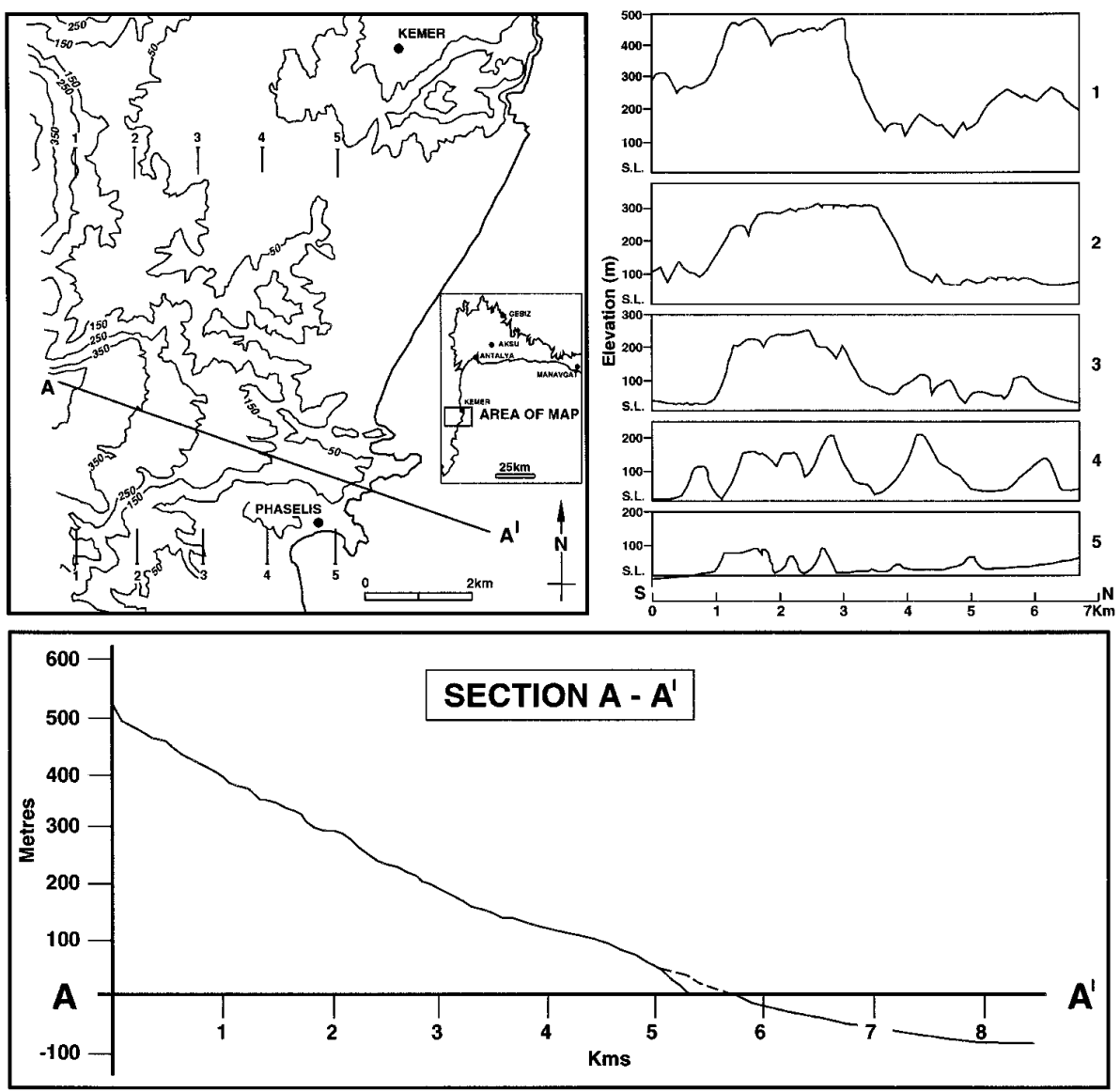

Fig. 16. Map view of the Phaselis fan with accurate cross-sections parallel (A-A $)$ and perpendicular (1-5). Profile $\mathrm{A}-\mathrm{A}^{\prime}$ shows the smooth slope of the Phaselis fan that can be traced offshore, but is interrupted by a sea-cliff at $7 \mathrm{~m}$ asl. Profiles 1-5 demonstrate the fluvial erosion of the fan, which increases in intensity downslope. Both are taken as evidence of uplift of the coastal area.

\section{Measurement}

\section{All Planes}

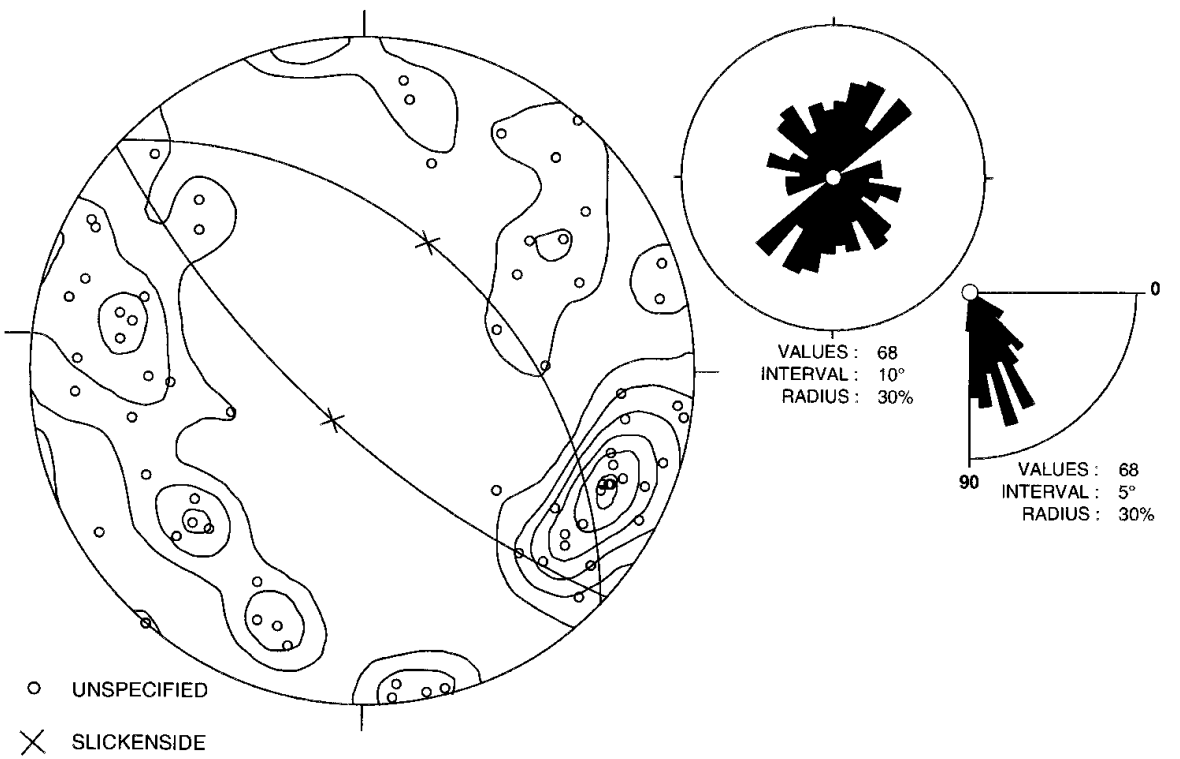

Fig. 17. Plots of fault data from the Pliocene sediments around Çalkaya. Main plot is a stereographic projection of poles to planes of all data, with the faults that gave a sense of direction plotted as great circles with slickensides. Both are normal faults. A rose diagram is plotted of fault plane strike (non-directional) of all data. The quarter plot is of fault plane dip direction.

would be expected. In addition, the sediments are relatively undeformed in most areas and dip uniformly and at a shallower angle than is anticipated in a shear zone. The similarity between fault directions measured in the Pliocene sediment around Çalkaya and those from the western margin zones suggests that all are related to neotectonic fault activity. However, the style of faulting affecting the Pliocene sediments cannot be further constrained owing to the lack of slickenside data.

\section{Summary of all fault data}

Table 2 summarizes the results obtained by earlier workers, while Table 3 summarizes the results of this study. Two 
Table 2. Published fault lineament directions in the Isparta Angle

\begin{tabular}{llll}
\hline Price \& Scott (1994) & Burdur grabens & NW-SE & Normal \\
Du Poux (1983) & Aksu Basin & N-S, NW-SE & $\sigma_{3}$ \\
& Bey Dağları & ESE-WSW & $\sigma_{3}$ \\
& & NNE-SSW & $\sigma_{2}$ \\
Değirminci \& Günay (1992) & Köprü Basin & NNW-SSE & Normal \\
& & NW-SE & Right-lateral \\
Aydar \& Dumont (1979) & Aksu Basin & NE-SW & Left-lateral \\
& & NE-SW & First generation \\
& & NW-SE & Second generation \\
& & N-S & Third generation \\
\hline
\end{tabular}

Table 3. Summary of fault orientation data collected during this study

\begin{tabular}{ll}
\hline Normal & \\
Kemer and Olympos & NNE-SSW \\
Çandır & NW-SE and NNW-SSE (most dominant) \\
Ovacık & NW-SE and N-S (tentative) \\
Ortaköy & NNW-SSE and N-S \\
Çalkaya & NW-SE \\
Right-lateral & \\
Kemer & NE-SW and NW-SE \\
Çandır & NE-SW \\
Ortaköy & NE-SW \\
Bucak & NE-SW and NNE-SSW (tentative) \\
Left-lateral & \\
Çandır & NNE-SSW and NW-SE \\
Ortaköy & WNW-ESE \\
Ovacık & E-W to SSE-NNW (large spread) \\
All planes & \\
Pınargözü & NNW-SSE \\
Antalya Road & NW-SE \\
\end{tabular}

Figure 14 highlights the areas where data were collected (Glover 1995).

principal fault directions, NE-SW and NW-SE, are indicated. In most areas, right-lateral and normal faults dominate. Leftlateral faulting is found around Çandır and Ortaköy and at Ovackk. The data from Ovacık and Kırkkavak are not considered good enough to draw any structural conclusions. Also, the Kurkkavak fault lineament was primarily active during the Miocene (Flecker 1995; Flecker et al. 1995). Data from Pınargözü and Antalya road strongly suggest that very strong fault reactivation has occurred in these areas, with clear superposition of fault phases. Reverse faulting, presumably related to the Late Miocene Aksu Phase, was followed by a phase of strike-slip faulting and then by a phase of normal faulting in these areas. Reverse faults measured in the principal data areas discussed above are statistically insignificant but suggest the same superposition of phases.

\section{Evidence of regional surface uplift}

A plot (Fig. 18) of the percentage of fall from the headwaters of the Aksu River against the percentage of length of the stream from its headwaters (after Bull \& Knüpfer 1987) shows that, whereas the lower reaches of the Aksu may be close to dynamic equilibrium, the upper reaches deviate greatly. The evidence that the Aksu River is out of equilibrium with a very steep gradient in the headwater region is suggestive of surface uplift. This can also be seen on cross sections through the Taurus Mountains (Fig. 18) and through the Aksu basin. In addition, the extensive nature of the tufa terraces is emphasized.
The Aksu River deposits form a series of terraces. These were mapped by Burger (1992) who identified terraces at $70 \mathrm{~m}$, $40 \mathrm{~m}$ and $25 \mathrm{~m}$. In this study the $70 \mathrm{~m}$ and $40 \mathrm{~m}$ terraces were traced throughout the Köprü and Manavgat Basins. Tectonic uplift as the sole cause of terrace formation is thought unlikely, as terraces incised into the bedrock are not identified and the fill is always several metres thick (Bull 1990). It is envisaged that climatic control of the sediment supply introduced coarse sediment into the basin during wet periods. These aggradation events are superimposed on a more general tectonic uplift, which isolated the terraces above the base level of erosion. This suggests that the aggradation events represent general (i.e. tectonics and climatic change) rather than local processes (i.e. local fluvial events).

With large fluctuations of sea level during the Pleistocene (Wornardt \& Vail 1991), flooding of the low-relief central Aksu Basin and the western coastal area would be anticipated. However, there is no evidence of marine incursion after Pliocene regression. Instead, for example, the mature slope surface of the Phaselis fan is clearly disrupted by a $75 \mathrm{~m}$ high cliff, caused by marine erosion of an uplifted slope surface (Fig 16 , Section $\mathrm{A}-\mathrm{A}^{\prime}$ ). Larger cliffs are cut in the other profiles, but it is not clear how much of this is due to faulting and how much due to regional uplift. Notches in the tufa along the Antalya coastline show that the sea cliffs are uplifted relative to present-day sea level.

There is, thus, considerable geological and geomorphological evidence that strong regional surface uplift has occurred throughout the Pleistocene and possibly for longer.

\section{Regional setting}

The Plio-Pleistocene sedimentary and tectonic evolution of the Aksu Basin can be compared with counterparts in Cyprus, the Adana Basin of southern Turkey, and more generally with the Aegean region further west (Fig. 1).

In the Adana Basin, adjacent to the eastern Mediterranean Sea and several hundred kilometres east of the Isparta Angle, fluvial deposition continued from the Late Miocene without any marked stratigraphic break. The Pliocene comprises fluvial and clastic deposition, with minor intercalations of channelized conglomerate and limestone. There is then a marked unconformity at the top of the Pliocene; followed by localized Pleistocene units that include fluvial clastics and volcanogenic sediments, in places cut by strike-slip faults (Karig \& Kozlu 1990; Gürbüz 1993).

The Adana-Cilicia Basin dominates offshore southern Turkey. It evolved as an extensional subsiding basin complex at least since the Late Miocene (Aksu et al. 1992; Kempler 

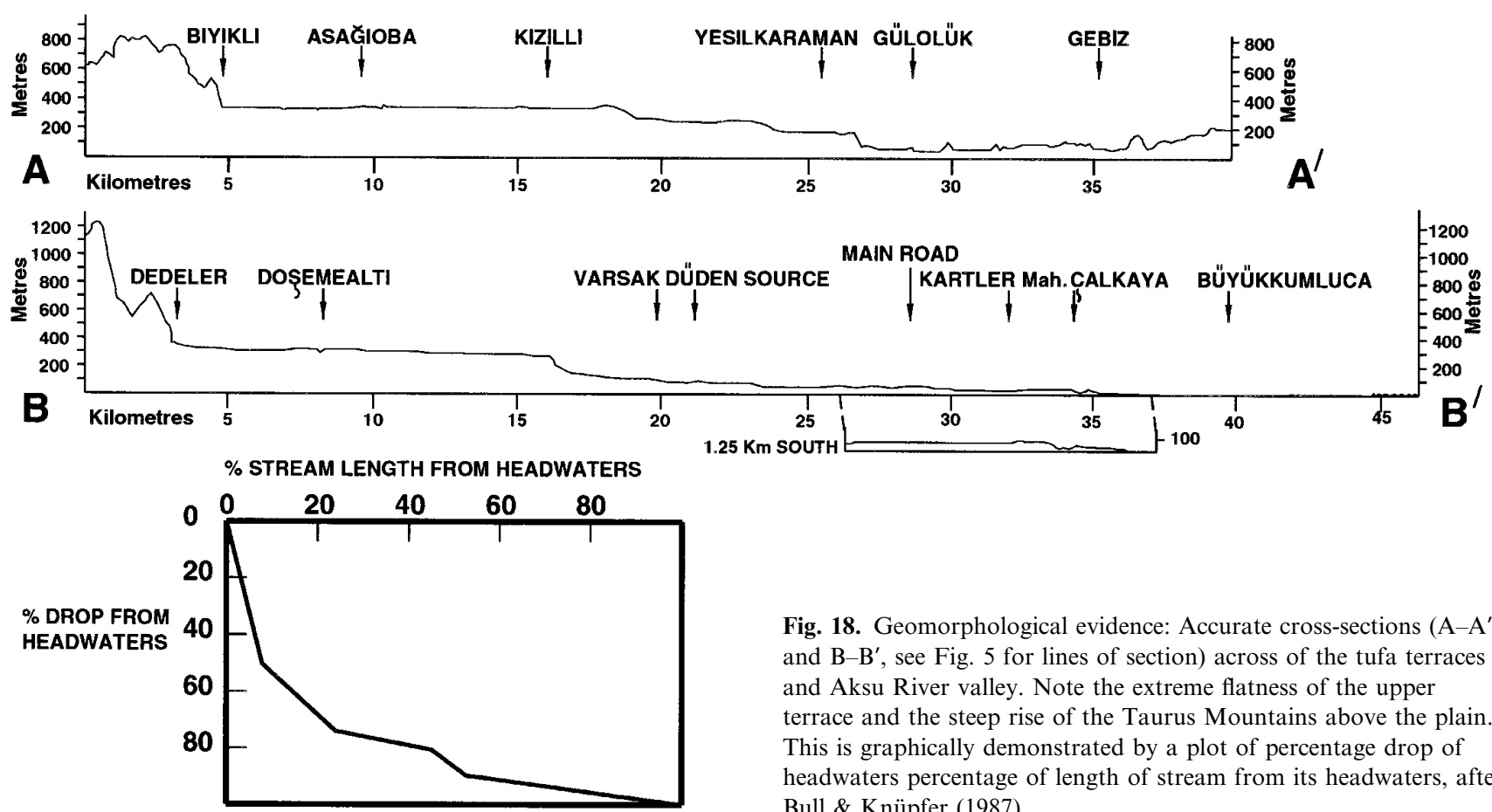

Fig. 18. Geomorphological evidence: Accurate cross-sections (A-A' and $\mathrm{B}-\mathrm{B}^{\prime}$, see Fig. 5 for lines of section) across of the tufa terraces and Aksu River valley. Note the extreme flatness of the upper terrace and the steep rise of the Taurus Mountains above the plain. This is graphically demonstrated by a plot of percentage drop of headwaters percentage of length of stream from its headwaters, after Bull \& Knüpfer (1987).

1994) and can be considered to be a back-arc basin complex related to southward 'roll-back' of the Cyprus active margin to the south (Robertson \& Grasso 1995).

Antalya Bay is also dominated by NE-SW extensional faulting that dates at least from the Late Miocene. The interpreted Messinian surface is faulted and infilled by Early Pliocene syn-sedimentary deposits. Antalya Bay can also be considered as a part of the 'back-arc' basin complex, although there was no contemporaneous arc volcanism. The main reason for the existence of the Isparta Angle re-entrant is that it was inherited from Mesozoic-Tertiary time as a long-lived zone of crustal weakness (i.e. a suture between several microplates) that was further exploited by crustal extension in Pliocene time.

The Cyprus active margin loops south of Cyprus and swings to the NW, along the Florence Rise, to connect with the eastward extension of the Aegean arc in the vicinity of the submarine Anaximander Mountains, adjacent to the southern Turkish coast (Anastakis \& Kelling 1991). The Florence Rise might be considered as a mud-dominated accretionary complex, similar to but smaller in scale than, the Mediterranean Ridge further west. Holocene, lithologies including Mesozoic limestone were dredged from the Anaximander Mountains, suggesting a correlation with the Mesozoic Susus Dağ and Bey Dağları carbonate massifs on land to the west of the Isparta Angle (Woodside \& Dumont 1997). The southern boundary of the Anaximander Mountains can be considered as a strike-slip dominated plate boundary segment linking the Florence Rise with the Aegean arc to the west (via the Strabo and Pliny trenches).

Further southwest, the south Aegean also underwent extensional faulting and subsidence from the Late Miocene onwards (Meulenkamp et al. 1988, 1994), as a regional response to southward migration of the Hellenic subduction zone south of Crete (Le Pichon \& Angelier 1979). This, in turn accommodated the westward 'escape' of Anatolia (Şengör et al. 1985).
The Plio-Pleistocene of Cyprus mainly accumulated in two basins: the Mesaoria basin in the north and the Polis graben in the west. The Mesaoria basin is interpreted as an $(\mathrm{E}-\mathrm{W})$ asymmetrical graben that was active through Late Miocene to Mid-Pliocene time (Follows \& Robertson 1990; McCallum \& Robertson 1990). The basin was infilled with marine hemipelagic sediments intercalated with minor terrigenous conglomerates and bioclastic carbonates shed from the Troodos ophiolite to the south (McCallum \& Robertson 1995). By contrast, in west Cyprus the Polis basin developed as an asymmetrical approximately $\mathrm{N}-\mathrm{S}$ graben mainly during Late Miocene time, followed by relatively passive infill of shelfdepth calcareous silty sediments, mostly during Early to Mid-Pliocene time (Payne \& Robertson 1995). In both basins, progressive shallowing upward took place in the Late Pliocene-early Pleistocene, associated with the beginning of strong uplift of Cyprus (Haughton et al. 1990; McCallum \& Robertson 1990). This uplift is attributed to collision of the Eratosthenes Seamount, an assumed continental fragment, with a subsiding margin south of Cyprus, combined with large-scale diapiric protrusion of serpentinite in the core of the Troodos Massif (i.e. Mt Olympus) (Robertson et al. 1995, 1996b).

There is considerable evidence to suggest that broad shear along the North Anatolian fault began in the Mid-Miocene about 12 Ma ago (Şengör et al. 1985; Barka \& Hancock 1984). This developed into a fully-fledged fault zone by the Pliocene, coupled with extension of the Aegean and western Turkey (Dewey \& Şengör 1979). In western Anatolia orogenic collapse of sutured Neotethyan orogen took place in the Late Oligocene-Early Miocene, coeval with the later stages of southwestward emplacement of the Lycian Nappes (Hayward 1984; Collins \& Robertson 1997) and gave rise to initial western Aegean grabens (Seyitoğlu et al. 1992; Seyitoğlu \& Scott 1996). Further rifting took place in the Late Miocene to produce the present graben morphology (Purvis \& Robertson 1997). Analysis of stress regimes in the western Turkish 
grabens (Angelier et al. 1981; Zanchi et al. 1993; Mercier et al. 1989) shows that a change in stress regime from N-S to NE-SW occurred in the Late Pliocene-mid-Pleistocene.

The Aksu Basin lies in the transitional area between extending western Turkey and the Aegean and the extruding/rotating Anatolian plateau. Its development through time is a result of the interaction of these two areas and the subducting arcs to the south. The Aksu Basin is in part an onshore continuation of the zone of 'back-arc' crustal extension and subsidence within Antalya Bay. By contrast, the Adana Basin that is closer to the Africa-Eurasia collision zone to the east was emergent from the Mid-Miocene onwards, and was influenced by localized compression and strike-slip in the Pliocene and Pleistocene, as the East Anatolian fault became fully active (Karig \& Kozlu 1990). The Polis and Mesaoria basins in Cyprus and the Aksu Basin show a common upward regression in the Late Pliocene-Early Pleistocene, in part related to eustatic sea-level fall. However, the tectonic-sedimentary history of these basins differs in detail. Late Pliocene-Pleistocene deposition in southern Cyprus was controlled by rapid localized uplift of the core of the Troodos ophiolite (i.e. Mt Olympus). The Aksu Basin in contrast was relatively tectonically quiescent during deposition of the Early-Mid-Pliocene sediments. Extensional faulting then formed a N-S-trending graben system. This faulting probably began during the MidPliocene when westward 'escape' of Anatolia intensified, and the stress regime in the western Aegean region changed to become more orthogonal (NE-SW) to the Aksu Basin (Angelier et al. 1981). The graben was then partly infilled with alluvial deposits and tufa. Relatively localized graben development was superimposed on regional uplift of the adjacent Tauride Mountains as part of Central Anatolia that underwent 'tectonic escape' towards the west (Şengör et al. 1984; Price \& Scott 1994).

\section{Sedimentary and tectonic evolution of the Pliocene-Pleistocene Aksu Basin}

Following genesis of the Oligo-Miocene Aksu Basin within the Isparta Angle and short-lived, localized compression in the Late Miocene (Aksu Phase), the scene was set for the Tortonian-Messinian (Late Miocene) to Holocene development of the Aksu Basin. The Aksu Basin experienced (NNE-SSW) transtension in the Tortonian? (Late Miocene) (Fig. 19). The deformation probably exploited pre-existing structural lines of weakness orientated slightly oblique to the principal stress direction. This transtension is believed to relate to the onset of extension in the Aegean, causing a right-lateral stress on the bounding area between the western extensional region and the newly 'escaping' Anatolian plateau.

Reef limestones (Gebiz Limestone) mainly developed above the pre-existing Aksu compressional lineament. Subsequent desiccation of the newly formed basin in the Messinian, led to deposition of evaporites, probably in small lagoons or silled basins, similar to the sub basins of Cyprus (Orszag Sperber et al. 1989; Robertson et al. 1995). Selenitic gypsum was locally observed in the Aksu Basin, but not in situ.

Flooding of the Mediterranean, after the Messinian salinity crisis, returned the basin to normal marine conditions. This resulted in deposition of the shallow-marine Pliocene Yenimahalle Formation, which laps onto the Tortonian Gebiz Limestone (Fig. 3); Mesozoic units further north, and onto Miocene basinal sediment in the southeast (Fig. 4). Deposition was largely controlled by Mediterranean-wide sea-level changes. Three transgressive phases are recognized from seismic lines in Antalya Bay. The Early Pliocene was a phase of relative tectonic quiescence when mature slope surfaces were developing in the Taurus Mountains, particularly in the west. Coarse fan deltas (the Kemer Fanglomerates) locally accumulated in areas of high relief (i.e. Antalya Bay western margin) and culminated in the development of mature slope profiles.

By the Late Pliocene-Early Pleistocene (Fig. 19) the Early Pliocene deposits in the Aksu Basin were tilted to the west by $\mathrm{NE}-\mathrm{SW}$ extension and pre-existing erosion surfaces began to be fault dissected, during an important period of extensional faulting. The driving force is seen as a regional change of maximum extension direction from sub-parallel $(\mathrm{N}-\mathrm{S})$ to orthogonal (NE-SW) with respect to the pre-existing $\mathrm{N}-\mathrm{S}$ and NNW-SSE structural weaknesses. This change is clearly demonstrated throughout the Aegean region (Angelier et al. 1981; Mercier et al. 1989; Zanchi et al. 1993). No fault activity is recognized on the eastern margin of the Antalya Basin at this time and the basin thus appears to be a half graben. The resulting uplift caused deep fluvial incision of mature slope surfaces on the western basin margin. The current degraded state of the major normal fault scarps suggests that normal faulting has been less intense during late Pleistocene to Holocene time.

Deposition of the Antalya tufa is thought to have occurred during the mid-Pleistocene, when climatically favourable conditions for extensive tufa deposition existed over a relatively long period (c. $0.5 \mathrm{Ma}$ ). A variety of lacustrine, paludal and fluvial environments developed and shallowed-up through time. The horizontal nature of the tufa stratification and the paucity of associated faulting indicate that the tufa was deposited after the principal normal faulting event. The differences in basement type in the east (i.e. Pliocene sands and conglomerates) versus the west (i.e. peridotite) is therefore explained as a response to accumulation on a highly irregular, block-faulted basement topography. Small, localized fanglomerates along the western margin of the area interfinger with tufa, suggesting that subsequent normal faulting may have increased run-off in the far west of the area. However, clastic supply to the area was not sufficient to swamp carbonate production. The location of the palaeo-Aksu River with its coarse sediment input might explain why tufa was not deposited further east.

These local events were all superimposed on regional surface uplift throughout the Pleistocene, that may have begun earlier. Subsidence of the basin related to early Pleistocene faulting was only on a relatively small scale compared to much larger-scale uplift of the Tauride Mountains, which formed a part of central Anatolia that 'escaped' westwards, bounded by the North Anatolian Fault to the north (Seyitoğlu et al. 1992, Price and Scott 1994).

Since the early mid-Pleistocene strong climatic fluctuations related to glacial cyclicity superimposed their effects on regional uplift of Anatolia and more local relative subsidence of the Aksu Basin as an extensional graben. Climatically controlled fluvial aggradation terraces developed in the central Aksu Basin. Terra rossa-type soils formed on the surface of Mesozoic limestone and in pockets in the tufa, and were redeposited in steep-sided channels cut into fluvial terrace conglomerates probably as a result of flash flood events. At the onset of the middle Pleistocene, global sea-level fluctuations became greater and it is possible that a marine incursion eroded the lower terrace. A small fan was deposited at the 

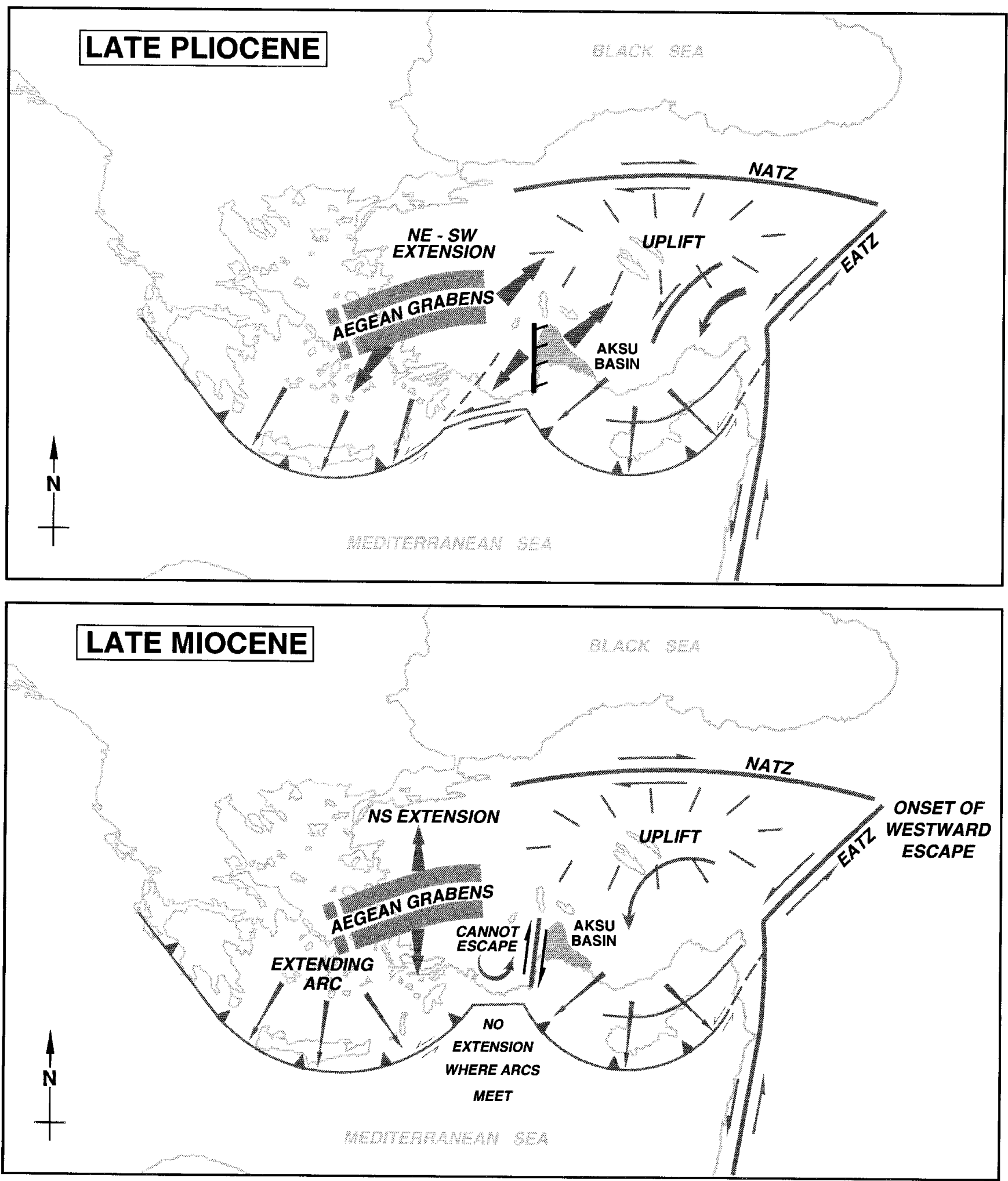

Fig. 19. Sketch diagrams of the regional tectonic regime during the Late Miocene and Late Pliocene and the resultant stresses on the Aksu basin. During the Late Miocene, as westward 'escape' of the Anatolian plateau begins, the Aksu basin is located at the boundary of the extending Aegean grabens (Aegean and western Turkey) and the uplifting and W/SW moving/rotating Anatolian plateau. Westward movement is taken up on the Aegean and Cyprus arcs, but not in the area just south of the western edge of the Aksu Basin, where the two arcs meet. The torque between the N-S-extending Aegean grabens and the westward moving Anatolian plateau causes a right-lateral stress on the pre-existing structural lineaments of the Isparta angle. This is a period of significant right-lateral movement along these faults. By the Late Pliocene that torque has been relieved by the Fethiye-Burdur fault zone and left-lateral movement on the Strabo trench (see Fig. 1 for geographic names). Also the regional stress regime has switched from NS to NE-SW resulting in an orthogonal stress on the pre-existing structural weaknesses. Thus, this period is one of normal faulting. 
mouth of the Karaman River at this time. However, no evidence of marine sediments has been found on the lower plain that is now very heavily karstified and vegetated. Burger (1990) suggested this was a karst marginal plain, at a $40-50 \mathrm{~m}$ level, related to a period of higher sea-level, but no direct supporting evidence was identified during this study.

At present, tectonic and sedimentary activity in the basin is minimal and erosional processes dominate. The tufa gradually collapses as cave systems undermine the structure and sinkholes develop (e.g. the spur north of Antalya). Fluvial incision eroded the terrace edges during glacial periods when runoff was high. The main present-day depositional processes include continued formation of fluvial terraces, related to the Aksu River and coastal marine erosion.

\section{Conclusions}

(1) The Late Miocene to Plio-Pleistocene Aksu Basin of the Isparta Angle area of southwestern Turkey documents tectonic-sedimentary processes at the interface of the uplifted Tauride Mountains to the north, the Eastern Mediterranean Sea to the south, and the extensional Aegean and western Turkey to the west.

(2) The Plio-Pleistocene Aksu Basin was initiated following a localized phase of compressional thrusting in the Late Miocene (Aksu Phase), related to a final stage of thrusting of the Lycian Nappes from the northwest. Initial sedimentation comprised localized Tortonian reef limestone, and gypsum of assumed Messinian age.

(3) During the Late Miocene-Early Pliocene the structure of the Aksu Basin, in particular its western margin, was influenced by right-lateral strike-slip, that exploited pre-existing structural weaknesses. This resulted from the interaction between the uplifting and extruding Anatolian plateau and the extending western Turkey and Aegean.

(4) A period of relative quiescence ensued in the Early Pliocene and the western margin of the Antalya basin developed a mature slope profile. As the slopes evolved fanglomerates were shed from the western margin of the basin (i.e. Kemer Fanglomerates). Following marine transgression at the beginning of the Pliocene, these sediments are viewed as contemporaneous with accumulation of Lower Pliocene marine sediments, based on lithological and geomorphological mapping.

(5) During the Early Pliocene, the Aksu Basin and adjacent areas further east (i.e. Manavgat Basin) underwent low-energy muddy sedimentation in an open-marine shelf-depth sea $(<150 \mathrm{~m})$. This was followed in the Late Pliocene by rapid regression (probably eustatically controlled) and deposition of a shallow-marine deltaic complex, sourced by a braided fluvial system.

(6) Shallow seismic evidence indicates that three cycles of Plio-Pleistocene deposits are present offshore in Antalya Bay, probably controlled by eustatic sea-level change in an area of active extensional faulting and subsidence. The Pliocene sediments drape a block-faulted topography that opened to the south as an asymmetrical graben. Much of the extensional faulting post-dates deposition of Early Pliocene deltaic sediments.

(7) During the Late Pliocene-early Pleistocene the Aksu Basin formed as a half-graben system in response to a combination of $\mathrm{N}-\mathrm{S}$ and NE-SW (i.e. orthogonal) extensional faulting, while the adjacent Tauride Mountains were progres- sively uplifted. Pre-existing coastal fanglomerates in the west were cut by normal faults.

(8) The extensive (up to 250 thick; areal extent $600 \mathrm{~km}^{2}$ ) cool-water Antalya tufa deposits probably accumulated during pre-glacial time, after extensional faulting had largely ceased within the main Aksu Basin. Initial deposition in small lakes was followed by dominantly algal deposition, with rapidly switching paludal to lacustrine and fluvial environments. Desiccation and fluvial reworking continuously modified the local topography. The source of carbonate-rich water was the adjacent Tauride Mountains (dominantly carbonate), with tens of kilometres of subterranean flow and supply to the Antalya plain through extensive springs, including the present-day Kırkgöz (forty springs).

(9) By the mid-Pleistocene, the major period of tufa deposition was over. During relatively humid glacial periods rivers, supplied by surface run off and subterranean streams, cut into the deposit. This created terraces in the tufa that were subsequently covered by a veneer of tufa, hiding the evidence of earlier fluvial erosion.

(10) Well-developed conglomerate terraces within the Aksu Basin are interpreted as fluvial in origin, related to sequential downcutting of the palaeo-Aksu River.

(11) In the regional tectonic context, the Aksu Basin documents initial Late Miocene-Late Pliocene oblique strike-slip, exploiting pre-existing zones of structural weakness. It is envisaged as part of a 'back-arc' basin complex behind the $\mathrm{N}$-dipping Africa-Eurasia plate boundary within the Eastern Mediterranean Sea. This was followed, in the Late Plioceneearly Pleistocene, by extension to form a N-S half-graben extending into Antalya Bay. The rifting was contemporaneous with regional uplift of the Tauride Mountains, as part of central Anatolia that underwent westward 'tectonic escape' towards the Aegean.

(12) Comparisons with other well-documented PlioPleistocene basins in the easternmost Mediterranean region (i.e. Adana Basin and Cyprus) confirm a strong influence of Mediterranean wide sea-level changes, increasingly dominated by tectonic uplift after the Mid-Pliocene.

The work particularly benefited from discussion with R. Flecker, A. Poisson, J. Dixon, D. Kroon, W. Austin, M. Pedley, J. Woodside and G. Schwiegert. We thank M. Ergün for making available the shallow seismic data. The work benefited from the helpful comments of P. Gibbard and an anonymous referee. Thanks go to A. Fallick at the Scottish Research and Reactor Centre East Kilbride for assistance with radiometric dating. A $\mathrm{PhD}$ studentship from Shell Expro (UK) held at the Department of Geology and Geophysics, University of Edinburgh, UK, supported the first author. Many thanks go to J. Mitchell and G. Muckle at Esso UK who helped redraft many of the diagrams.

\section{References}

Akay, E. \& Uysal, S. 1985. Orta toroslarin batısindaki (Antalya) Neojen çökellerinin stratigrafisi, sedimentolojisi ve yapısal jeolojisi. MTA.

—, Uysal, S., Poisson, A., Cravatte, J. \& Müller, C. 1985. Antalya Neojen havzasinın stratigrafisi. Bulletin of the Geological Society of Turkey, 28, $105-119$.

Anastasakis, G. \& Kelling, G. 1991. Tectonic connection of the Hellenic and Cyprus arcs and related geotectonic elements. Marine Geology, 97, 261277.

Angelier, J., Dumond, J.-F., Karamanderesi, H., Poisson, A., Simsek, S. \& Uysal, S. 1981. Analysis of fault mechanisms and expansion of southwestern Anatolia since the Late Miocene. Tectonophysics, 75, T1-T9. 
Aksu, A.E., Calon, T., Piper, D.J.W., Turgul, S. \& Izdar, E. 1992. Architecture of Late orogenic basins in northeastern Mediterranean Sea. Tectonophysics, 210, 191-213.

Aydar, C. \& Dumont, J.F. 1979. Antalya travertınlerindegörülen dizilmelerde elde edilen Landsatgoruntuleri uzerinde yapilan gozlemler: Neotektonik ve hidrojeoloji arasinda olabilecek baĝıntıların tartısmașı. Maden Tektik ve Arama Enstitusu dergisi, Nisan, 1979 92, 131-134.

BARKA, A.A. \& HanCOCK, P. 1984. Neotectonic deformation patterns in the convex northwards arc of the North Anatolian fault zone. In: Dixon, J.E. \& Robertson, A.H.F. (eds) The Geological Evolution of the Eastern Mediterranean. Geological Society of London, Special Publications, 17, 763-774.

Bergrenn, W.A., Kent, D.V., Swisher, C.C., III \& Aubry, M.-P. 1995. A revised Cenozoic geochronology and chronostratigraphy. In: Chronology Time Scales and Global Stratigraphical Correlation, SEPM Special Publications, 54, 129-212.

Bougeors, J. \& Leithold, E.L. 1984. Wave-worked conglomeratesdepositional processes and criteria for recognition. In: KosTER, E.H. \& SteEL, R.J. (eds) Sedimentology of gravels and conglomerates. Canadian Society of Petroleum Geologists, Memoirs, 10, 331-343.

Buccino, G., D’Argenio, B., Ferreri, V., Brancaccio, I., Ferreri, M., Panichi, C. \& Stanzione, D. 1978. I Travertini della bassa valle del Tanagro (Campania). Studio Geomorphologico, Sedimentologico e Geochimico. Bolletino della Società Geologica Italiana, 97, 617-646.

Bull, W.B. 1990. Stream terrace genesis: implications for soil development. Geomorphology, 3, 251-367.

\& KNÜPFER, P.L.K. 1987. Stream adjustment to uplift and climatic change, Charwell River, New Zealand. Geomorphology, 1, 15-32.

Burger, D. 1990. The Travertine Complex of Antalya/Southwest Turkey. Zeitschrift für Geomorphologie. Neue Forschung. Suppl. Bd 77, 25-46.

— 1992. Quantifizierung Quartärer subtropischer verwitterung auf kalk: das Beispiel Travertinkomplex von Antalya - Südwesttürkei. Gebrüder Borntraeger, Berlin, Stuttgart.

Clifton, H.E. 1973. Pebble segregation and bed lenticularity in wave-worked versus alluvial gravel. Sedimentology, 20, 173-187.

Collins, A.S. \& Robertson, A.H.F. 1997. Lycian melange, southwestern Turkey: an emplaced Late Cretaceous accretionary complex. Geology, 25, 255-258.

DeĞIrminci, M. \& GünAy, G. 1992. Analysis of hydrologic relations between Eğridir-Beyşehir-Sugla Lakes system and adjacent basins by means of remote sensing techniques (southern Turkey). Environmental Geology and Water Sciences, 19, 41-45.

Dewey, J.F. \& ŞENGÖR, A.M.C. 1979. Aegean and surrounding regions: complex multiplate and continuum tectonics in a convergent zone. Geological Society of America Bulletin, 90, 84-92.

Du Poux, B. 1983. Etude comparee de la tectonique des bassins au sud de Chypre et du bassin d'Antalya (Turquie). MSc thesis, Universite de Paris-Sud, Orsay.

Fisher, R.V. \& Schminke, H.-U. 1984. Pyroclastic rocks. Springer Verlag, Berlin.

FLeCKer, R.M. 1995. Miocene basin evolution of the Isparta angle, S. Turkey $\mathrm{PhD}$ thesis, University of Edinburgh.

— Robertson, A.H.F., Poisson, A. \& Müller, C. 1995. Facies and tectonic significance of two contrasting Miocene basins in south coastal Turkey. Terra Nova, 7, 221-232.

Folk, R.L. 1974. Petrology of sedimentary rocks. Hemphill Publishing Company, Austin, Texas, 159.

Follows, E.J. \& Robertson, A.H.F. 1990. Sedimentology and structural setting of Miocene reefal limestones in Cyprus. In: Moores, E.M. ET AL. (eds) Ophiolites in Oceanic Crustal Analogues. Proceedings of the Symposium "Troodos 1987". Geological Survey Department, Nicosia, 207-217.

Frizon de Lamotte, D., Poisson, A., Aubourg, C. \& Temiz, H. 1995. Chevauchements post Tortoniens vers L'ouest puis vers le sud au coeur de l'Angle d'Isparta (Taurus, Türquie). Conséquences Géodynamiques. Bulletin de la Société Géologique de France, 166, 57-66.

Frostick, L.E. \& ReID, I. 1989. Climatic versus tectonic controls of fan sequences: lessons from the Dead Sea, Israel. Journal of the Geological Society, London, 146, 527-538.

Glover, C.P. 1995. Plio-Pleistocene sediments and neotectonics of the Isparta Angle, SW Turkey. PhD Thesis, University of Edinburgh.

GÜRBÜZ, L. 1993. Identification and evolution of Miocene submarine fans, in the Adana Basin, Turkey. PhD Thesis, Keele University.

Gvirtsman, G. \& Buchbinder, B. 1978. Holocene and Pleistocene coral reefs and coastal sediments of the Gulf of Elat. Post-congress guidebook. In: Tenth International Congress of Sedimentology, Jerusalem, 163-189.
Haughton, J.D., Jenkyns, D.G., Xenophontos, C. \& Gass, I.G. 1990. Microfossil evidence for latest Pliocene ages for Arnathus and Khirokitia channel deposits, southern Cyprus, and thereby the uplift of the Troodos Massif. In: Moores, E.M. et AL. (eds) Ophiolites in Oceanic Crustal Analogues. Proceedings of the Symposium 'Troodos 1987'. Geological Survey Department, Nicosia, 231-234.

Hayward, A.B. 1984. Miocene clastic sedimentation related to the emplacement of the Lycian Nappes and the Antalya Complex, SW Turkey. In: DixoN, J.E. \& Robertson, A.H.F. (eds) The Geological Evolution of the Eastern Mediterranean. Geological Society, London, Special Publications, 17, 287 300 .

Heimann, A. \& Sass, E. 1989. Travertines in the Northern Hula Valley, Israel. Sedimentology, 36, 95-108.

Karig, D.E. \& KozLu, H. 1990. Late Paleogene-Neogene evolution of the triple junction region near Maras, south-central Turkey. Journal of the Geological Society, London, 147, 1023-1034.

KeMPLER, D. 1994. Tectonic patterns in the Eastern Mediterranean. PhD Thesis, Hebrew University, Jerusalem, Israel.

Kissel, C. \& Poisson, A. 1986a. Etude paléomagnetique preliminaire des formations Cénozoiques des Bey Dağlari (Taurides occidentales-Türquie). Comptes Rendus de l'Académie des Sciences, Paris, 302, Serie 11 (8), 343-348.

\& $\&$ 1986b. Etude paleomagnetique preliminaire des formations Neogene du bassin d'Antalya (Taurides occidentales-Türquie). Comptes Rendus de l' Académie des Sciences, Paris, 302, Serie 11 (810), 711-716.

—, Averbuch, O., Frizon de Lamotte, D., Monod, O. \& Allerton, S. 1993. First Paleomagnetic evidence for a post Eocene clockwise rotation of the western Taurides thrust belt east of the Isparta re-entrant (southwestern Turkey). Earth and Planetary Science Letters, 117, 1-14.

Kubièna, W.L. 1953. The soils of Europe. Thomas Murby and Co., London.

Kumar, N. \& SANDERS, J.E. 1976. Characteristics of modern shoreface deposits: modern and ancient examples. Journal of Sedimentary Petrology, 46, 145-162.

Le Pichon, X. \& Angelier, J. 1979. The Hellenic arc and trench system: A key to the Neotectonic evolution of the Eastern Mediterranean area. Tectonophysics, 60, 1-42.

Lefèvre, C., Bellon, H. \& Poisson, A. 1983. Présence de leucites dans le volcanisme pliocène de la région d'Isparta (Taurides occidentales, Türquie). Comptes Rendus de l'Académie des Sciences, Paris, 297, Série II, 367-372.

McCallum, J.E. \& Robertson, A.H.F. 1990. Pulsed uplift of the Troodos Massif - evidence from the Plio-Pleistocene Mesaoria basin. In: MalPas, J., Moores, E.M., Panayiotou, A. \& Xenophontos, C. (eds) Ophiolites, oceanic crustal analogues. Proceedings of the Symposium 'Troodos 1987'. Geological Survey Department, Nicosia, 217-230.

\& 1995. Sedimentology of two fan delta systems in the Plio-Pleistocene of the Mesaoria basin. Sedimentary Geology, 98, 215-244.

McKenzie, J.A., Palmer, S.C. \& Muller, P.A. 1990. Strontium isotope stratigraphy of the deep-sea type section at hole ODP 653A. In: KASTENS, K.A., Mascle, J. et AL., Proceedings of the Ocean Drilling Project, Scientific Results, 107, College Station, Texas, 405-414.

MARKer, M.E. 1971. Waterfall tufas: A facet of karst geomorphology in South Africa. Zeitschrift für Geomorphologie. Neue Forschung. Suppl. Bd 12, $138-152$.

Mercier, J.L., Sorel, D., Vergeley, P. \& Simeakis, C. 1989. Extensional tectonic regimes in the Aegean basins during the Cenozoic. Basin Research, 2, 49-71.

Meulenkamp, J.E., Van der Zwaan, G.J. \& Van Wamel, W.A. 1994. On the Late Miocene of Holocene vertical movements in the Cretan segment of the Hellenic arc. Tectonophysics, 234, 57-72.

—, Wortel, M.J.R., Wamel Van, W.A., Spakman, W. \& Hoogerduyn Strating, E. 1988. On the Hellenic subduction zone and the geodynamic evolution of Crete since the late Middle Miocene. Tectonophysics, 146, 203-215.

Meusel, H., JäGer, E. \& Weinert, E. 1965. Vergleichende chronologie der Zentral-europäischen Flora, I. G. Fischer, Jena.

Miall, A.D. 1978. Summary of braided river deposits. In: Miall, A.D. (ed.) Fluvial sedimentology. Canadian Society of Petroleum Geologists, Memoirs, 5, 597-604.

Murray, J.W. 1991. Ecology and palaeoecology of benthic foraminifera. Longman/The Palaeontological Association.

Nemec, W. 1990. Aspects of sediment movement on steep deltas. In: Colella, A. \& Prior, D.B. (eds) Coarse-grained deltas. Special Publications of the International Association of Sedimentologists, 10. Blackwell Scientific Publications, 29-73.

_ \& Postma, G. 1993. Pleistocene alluvial fans in southwestern Crete: sedimentation processes and geomorphic evolution. Special Publication of the International Association of Sedimentologists, 17, 235-276. 
— \& Steel, R.J. 1984. Alluvial and coastal conglomerates: their significant features and some comments on gravelly mass-flow deposits. In: KosTer, E.H. \& STEEL, R.J. (eds) Sedimentology of Gravels and Conglomerates. Memoir of the Canadian Society of Geological, 10, 1-31.

Ordóñez, S. \& García del Cura, M.A. 1983. Holocene and Tertiary fluvial carbonates in central Spain. In: Collinson, J.D. \& Lewin, J. (eds) Modern and ancient fluvial systems. Special Publication of the International Association of Sedimentologists, 6, 485-497.

Orszag-Sperber, F., Rouchy, J.-M. \& Elion, P. 1989. The sedimentary expression of regional tectonic events during the Miocene-Pliocene transition in the Southern Cyprus basins. Geological Magazine, 126, 291-299.

Özgür, N., Pekděger, A., Schneider, H.-J. \& Bílgín, A. 1990. Pliocene volcanism of the Gölçük area, Isparta/western Taurides. In: SAVASçIN, M.Y. \& Eronat, A.H. (eds) Proceedings of the International Earth Sciences Congress on Aegean regions, Volume II, IESCA Publications 2, 411-419.

Özüs, S. 1992. Antalya Travertines, hydrology and geochemistry. PhD Thesis, University of Çukarova, Adana, Turkey.

PAyne, A.S. \& Robertson, A.H.F. 1995. Neogene supra-subduction zone extension in the Polis graben system, west Cyprus. Journal of the Geological Society, London, 152, 613-628.

Pedley, H.M. 1990. Classification and environmental models of cool freshwater Tufas. Sedimentary Geology, 68, 143-154.

Pettijohn, F.J. 1975. Sedimentary rocks, Harper and Row, New York.

PICARD, M.D. 1971. Classification of fine-grained sedimentary rocks. Journal of Sedimentary Petrology, 41, 230-242.

Planhol, X. DE 1956. Position stratigraphique et signification morphologie des Travertins Subtauriques de L'Anatolie Sud-occidental. In: Report of the IV International Congress on the Pleistocene, Rome-Pisa, 467-471.

Poisson, A. 1977. Récherches géologiques dans les Taurides occidentales (Turquie). PhD Thesis, Université de Paris-Sud.

-, Orsay, A., Akay, E., Dumont, J.-F. \& Uysal, S. 1984. The Isparta Angle: a Mesozoic palaeorift in the Western Taurides. In: Tekeli, O. \& Gönçüoglu, C. (eds) International Symposium on the Geology of the Taurus Belt. MTA, Special Publications, Ankara.

Postma, G. 1990. Depositional architecture and facies of river and fan deltas: a synthesis. In: Colella, A. \& Prior, D.B. (eds) Coarse-grained deltas. Special Publications of the International Association of Sedimentologists, 10. Blackwell Scientific Publications, 13-27.

Price, S.P. \& ScotT, B. 1994. Fault-block rotations at the edge of a zone of continental extension; southwest Turkey. Journal of Structural Geology, 16, 381-392.

Purvis, M. \& Robertson, A.H.F. 1997. Multiphase rifting in rapidly extending crust (West Turkey). In: European Union of Geosciences, Strasbourg, March, 1977, Abstract.

Robertson, A.H.F. 1993. Mesozoic-Tertiary sedimentary and tectonic evolution of Neotethyan carbonate platforms, margins and small ocean basins in the Antalya Complex, SW Turkey. In: Frostick, L.E. \& STEEL, R. (eds) Sedimentation, Tectonics and Eustasy: Sea-level changes at active margins. Special Publications of the International Association of Sedimentologists, 20, 415-465.

\& Grasso, M. 1995. Overview of the Late Tertiary-Holocene tectonic and palaeo-environmental development of the Mediterranean region. Terra Nova, 7, 114-127.

\& Woodcock, N.H. 1984. The SW segment of the Antalya Complex, Turkey as a Tethyan Mesozoic-Tertiary continental margin. In: DixoN, J.E. \& Robertson, A.H.F. (eds) The Geological Evolution of the Eastern Mediterranean. Geological Society, London, Special Publications, 17, 251271.
- Clift, P.D., Degnan, P. \& Jones, G. 1991. Palaeogeographic and palaeotectonic evolution of the Eastern Mediterranean Neotethys. Palaeogeography, Palaeoclimatology, Palaeoecology, 87, 289-344.

- Dixon, J.E., Brown, S., Collins, A., Morris, A., Pickett, E., Sharp, I \& UstaÖMER, T. 1996a. Alternative tectonic models for the late PalaeozoicEarly Tertiary development of Tethys in the Eastern Mediterranean region. In: Morris, A. \& Tarling, D.H. (eds) Palaeomagnetism and Tectonics of the Mediterranean Region. Geological Society, London, Special Publications, 105, 239-263.

—, Eaton, S., Follows, E. \& Payne, A.S. 1995. Depositional processes and basin analysis of Messinian evaporites in Cyprus. Terra Nova, 7, 254-264.

— \& the Scientific Party 1996b. Role of the Eratosthenes Seamount in collisional processes in the Eastern Mediterranean. In: EMEIS, K.-C., Robertson, A.H.F., Richter, C. ET AL., 1986. Proceedings of the Ocean Drilling Program, Initial Reports, 160, 513-520.

Rust, B.R. 1978. Depositional models for braided alluvium. In: Miall, A.D (ed.) Fluvial sedimentology. Canadian Society of Petroleum Geologists, Memoirs, 5, 605-625.

ŞEngör, A.M.C., Görür, N. \& ŞARöGlu, O. 1985. Strike-slip faulting and related basin formation in zones of tectonic escape: Turkey as a case study. In: Biddle, K.T. \& Christie Blick, N. (eds) Strike-slip deformation, basin formation and sedimentation. SEPM Special Publications, 37, 227-264

- Y Ylmaz, Y. \& Sungurlu, O. 1984. Tectonics of the Mediterranean Cimmerides: nature and evolution of the western termination of Palaeotethys. In: Dixon, J.E. \& Robertson, A.H.F. (eds) The Geological Evolution of the Eastern Mediterranean. Geological Society, London Special Publications, 17, 77-112.

Seyitoglu, G. \& Scott, B.C. 1996. The cause of N-S extensional tectonics in western Turkey: Tectonic escape vs Back-arc spreading vs orogenic collapse. Journal of Geodynamics, 22, 143-153.

— \& RundLe, C.C. 1992. Timing of Cenozoic extensional tectonics in west Turkey. Journal of the Geological Society, London, 149, 533-538.

Stewart, I.A. \& Hancock, P.L. 1989. Normal fault zone evolution and fault scarp degradation in the Aegean region. Basin Research, 1, 139-153.

Szulc, J. \& Cwizewicz, M. 1988. The Lower Permian freshwater carbonates of the Slawkow graben, southern Poland: sedimentary facies context and stable isotope study. Palaeogeography, Palaeoclimatology, Palaeoecology, 70, 107-120.

Thunnell, R., Williams, D., Tappa, E. \& Raffi, I. 1990. Plio-Pleistocene stable isotope record for Ocean Drilling Program site 653, Tyrrhenian basin: implications for the paleoenvironmental history of the Mediterranean Sea. In: Kastens, K.A., Mascle, J. et al. Proceedings of the Ocean Drilling Program, Scientific Results, 107, College Station, Texas, 387-399.

WornardT, W.W. \& VAIL, P.R. 1991. Revision of the Plio-Pleistocene cycles and their application to sequence stratigraphy and shelf and slope sediments in the Gulf of Mexico. Transactions of the Gulf Coast Association Geological Society, 41, 719-744.

Woodcock, N.H. \& Robertson, A.H.F. 1982. Wrench and thrust tectonics along a Mesozoic-Cenozoic continental margin: Antalya Complex, SW Turkey. Journal of the Geological, Society, London, 139, 147-163.

Woodside, J. \& Dumont, J.F. 1997. The Anaximander Mountains are a southward and foundered part of the Southwestern Turkish Taurus. Terra Nova, 9, 394.

Zanchi, A., Kissel, C. \& Tapirdamaz, C. 1993. Late Cenozoic and Plei Pleistocene brittle continental deformation in western Turkey. Bulletin de la Société Géologique de France, 164, 507-517.

Received 3 March 1997; revised typescript accepted 4 July 1997.

Scientific editing by Alex Maltman. 